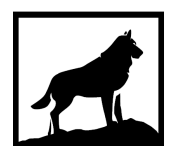

Michigan Technological

1 в 8 5 University
Michigan Technological University Digital Commons @ Michigan Tech

EVALUATING LONG-TERM GROWTH AND YIELD IN UPPER GREAT LAKES REGION NORTHERN HARDWOODS CUTTING TRIALS

Maeve Draper

Michigan Technological University, mcdraper@mtu.edu

Copyright 2021 Maeve Draper

Recommended Citation

Draper, Maeve, "EVALUATING LONG-TERM GROWTH AND YIELD IN UPPER GREAT LAKES REGION NORTHERN HARDWOODS CUTTING TRIALS", Open Access Master's Thesis, Michigan Technological University, 2021.

https://doi.org/10.37099/mtu.dc.etdr/1209

Follow this and additional works at: https://digitalcommons.mtu.edu/etdr

Part of the Forest Management Commons 


\title{
EVALUATING LONG-TERM GROWTH AND YIELD IN UPPER GREAT LAKES REGION NORTHERN HARDWOODS CUTTING TRIALS
}

\author{
By \\ Maeve C. Draper
}

\begin{abstract}
A THESIS
Submitted in partial fulfillment of the requirements for the degree of MASTER OF SCIENCE

In Forestry
\end{abstract}

MICHIGAN TECHNOLOGICAL UNIVERSITY

2021

(C) 2021 Maeve C. Draper 
This thesis has been approved in partial fulfillment of the requirements for the Degree of MASTER OF SCIENCE in Forestry.

College of Forest Resources and Environmental Science

Thesis Advisor: $\quad$ Dr. Robert E. Froese

Committee Member: $\quad$ Dr. Christel C. Kern

Committee Member: Dr. Yvette L. Dickinson

College Dean: Dr. Andrew J. Storer 


\section{Table of Contents}

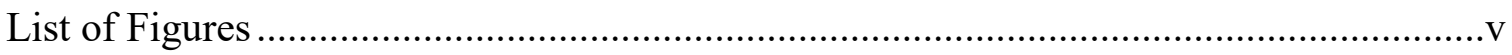

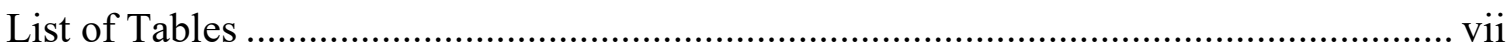

Author Contribution Statement............................................................................. ix

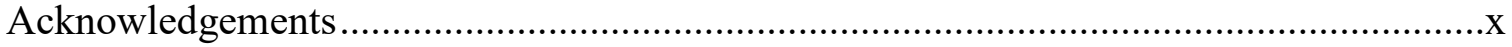

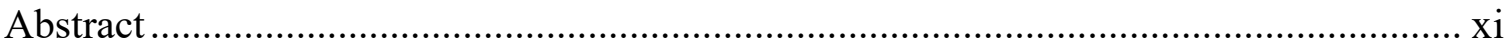

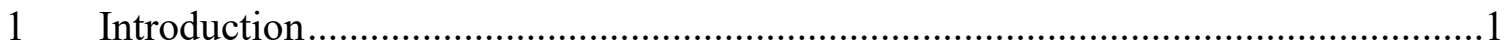

2 Six Decades of Financial Returns and Stand Dynamics in the Ford Forest Cutting

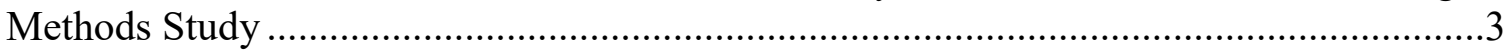

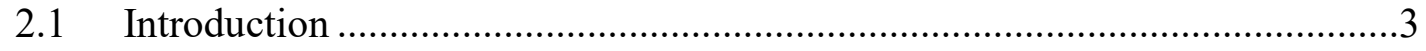

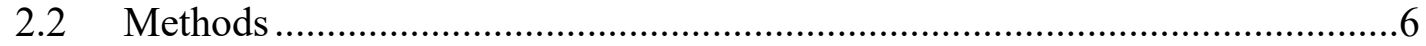

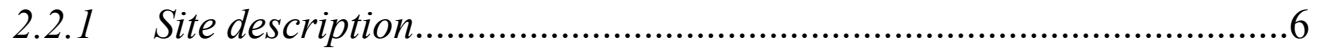

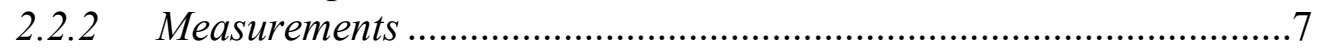

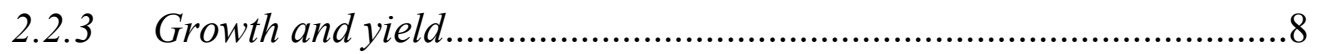

2.2.4 Financial analysis ...........................................................................9

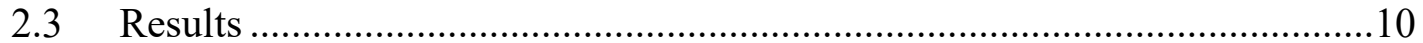

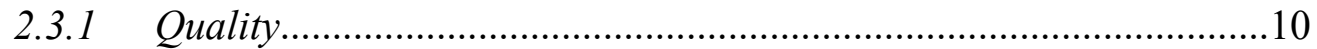

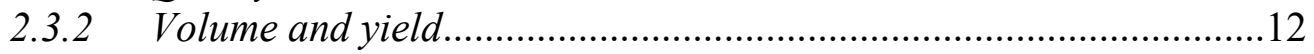

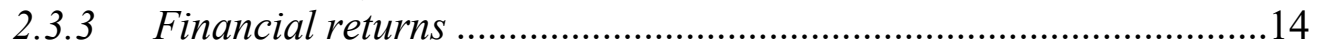

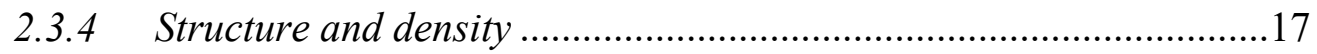

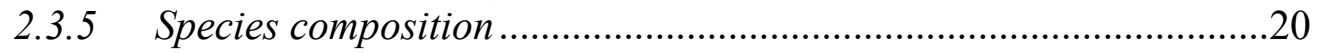

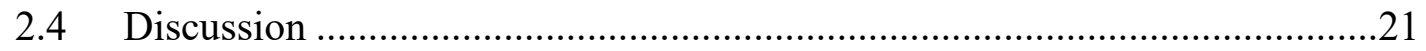

3 Six Decades of Financial Returns and Stand Dynamics in the Argonne Experimental Forest Cutting Methods Study ..................................................................2

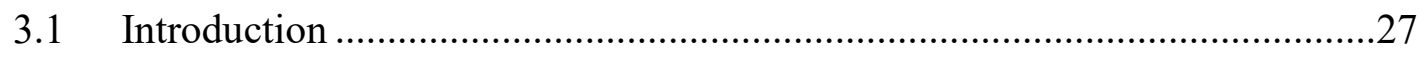

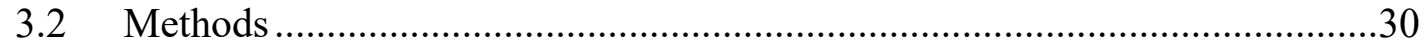

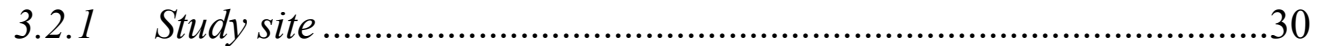

3.2.2 Long-term study design ..................................................................

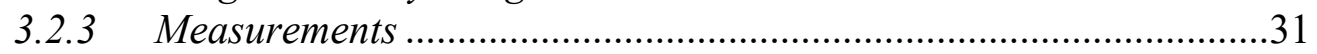

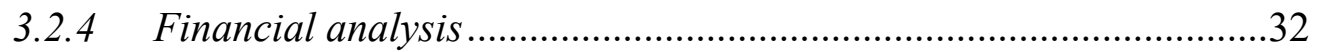

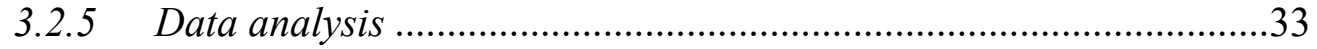

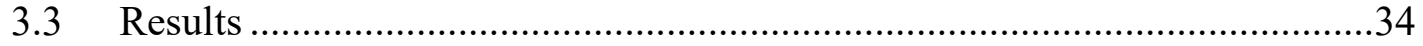

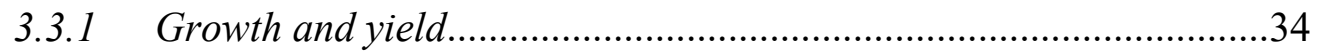

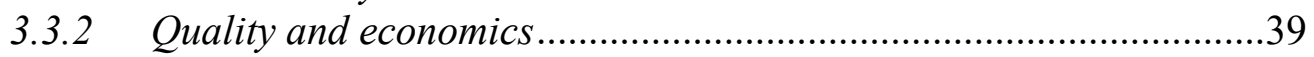


3.3.3 Structure and composition .......................................................4 41

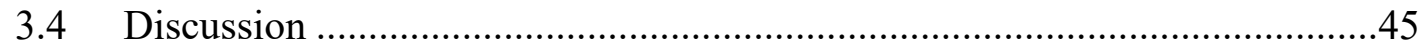

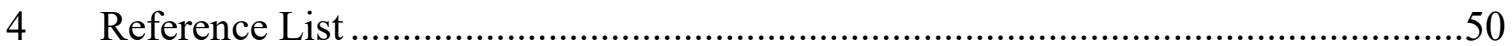

A Summary Information for the Cutting Methods Studies.......................................61

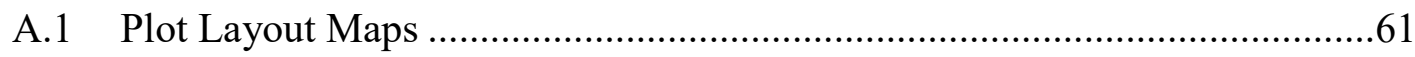

A.2 Studies Summary Table........................................................................6 63 


\section{List of Figures}

Figure 2. 1 Ford Forest pre-harvest standing tree butt log grade distribution (\%) by grade as measured in 1968, 1988, and 2018 in 0.4-hectare measurement units, for trees $>28 \mathrm{~cm} \mathrm{dbh}$ (Erickson et al. 1990). Non-merchantable (nm) class consists of trees $>28 \mathrm{~cm}$ dbh without any merchantable volume, as well as cull trees. Grade 1 includes veneer.

Figure 2. 2 Net residual standing sawtimber volume $\left(\mathrm{m}^{3} \mathrm{ha}^{-1}\right.$, from 0.4 -ha measurement units) over the 62-year study period (Int'1 1/4" Rule, following Gevorkiantz and Olsen (1955)) at the Ford Forest. Conversion from board feet to cubic meters following Winn et al. (2020). Data not available postharvest for 1968 and 1978 .

Figure 2. 3 Ford Forest net scaled harvested sawtimber volume by grade (percent of total $\mathrm{m}^{3} \mathrm{ha}^{-1}$ ) and treatment (Int'l 1/4" Rule, following Gevorkiantz and Olsen (1955)) from 1978 - 2018. Volumes derived from entire-treatment unit removals. Conversion from board feet to cubic meters following Winn et al. (2020)

Figure 2. 4 Cumulative revenue since 1978 in 2018 dollars by treatment at the Ford Forest: (A) $0 \%$ discount rate, (B) 2\% discount rate, and (C) 4\% discount rate.

Figure 2. 5 Ford Forest: (A) Stand structure pre-harvest at study commencement in 1956 for trees $\geq 12.6 \mathrm{~cm} \mathrm{dbh}$. The $50 \mathrm{~cm}$ class contains all trees in larger diameter classes. (B) Stand structure pre-harvest in 1998 for trees $\geq 12.6 \mathrm{~cm}$ dbh. (C) Stand structure pre-harvest in 2018 for trees $\geq 12.6 \mathrm{~cm} \mathrm{dbh}$.

Figure 2. 6 Ford Forest post-harvest stand density over time for all treatments, excluding the $13 \mathrm{~cm}$ DL cut, in terms of (A) number of trees $\left(\right.$ stems $\left.^{\cdot} \mathrm{ha}^{-1}\right)$ and (B) basal area $\left(\mathrm{m}^{2} \cdot \mathrm{ha}^{-1}\right)$.

Figure 3.1 Average annual ingrowth (into the smallest measured size class), mortality $\left(\mathrm{m}^{2} \mathrm{ha}^{-1} \mathrm{yr}^{-1}\right)$, and removals $\left(\mathrm{m}^{2} \mathrm{ha}^{-1} \mathrm{yr}^{-1}\right)$, for the entire study period at the Argonne EF. Within each graph (A, B, C) bars with the same letter are not significantly different, $p<0.05, n=15$.

Figure 3.2 Stand density through time for trees $\geq 11.4 \mathrm{~cm} \mathrm{dbh}$ at the Argonne EF. A) Basal area and B) trees per hectare from $1951-2016$.

Figure 3.3 Argonne EF net residual sawtimber volume ( $\mathrm{m}^{3} \mathrm{ha}^{-1}$, Intl. 1/4" rule) estimated by number of logs following Gevorkiantz and Olsen (1955) for 
trees $>24 \mathrm{~cm} \mathrm{dbh}$. Conversion to cubic meters following Winn et al.

Figure 3.4 Argonne EF average annual dry factory grade sawn lumber yield since 1972 (estimated following Hanks (1976), $\mathrm{m}^{3} \mathrm{ha}^{-1} \mathrm{yr}^{-1}$ ) by grade. Panels A-C for grades 1-3, respectively. Grade $1 \mathrm{C}+$ includes selects and better. Within each graph (A, B, C) bars with the same letter are not significantly different, $p<0.05, n=15$. Conversion to cubic meters following Winn et al. 2020.....38

Figure 3.5 For trees $>24 \mathrm{~cm}$ dbh at the Argonne EF, average proportion of trees in each grade as measured in 2016, following Hanks (1976).

Figure 3.6 Argonne EF stand structure through time for trees $>12.4 \mathrm{~cm} \mathrm{dbh}$. At commencement of study (A, 1951, pre-harvest), at time of last analysis (B, 1992, post-harvest), and at most recent measurement (C, 2016, 4-years post-

harvest).

Figure A.1.1 Ford Forest Study Layout.....................................................61

Figure A.1.2 Argonne Example Treatment Plot .............................................62 


\section{List of Tables}

Table 2. 1 Ford Forest grade distribution (\%) in 2018 by size classes corresponding to $\log$ grading rules threshold diameters.

Table 2. 2 Net residual standing sawtimber volume $\left(\mathrm{m}^{3} \mathrm{ha}^{-1}\right.$, from 0.4 -ha measurement units) over the 62-year study period (Int'l 1/4" Rule, following Gevorkiantz and Olsen (1955)) at the Ford Forest. Conversion from board feet to cubic meters following Winn et al. (2020). Post-harvest values are shaded in grey; data are not available post-harvest for 1968 and 1978.

Table 2. 3 Ford Forest net scaled harvested sawtimber volume by grade (percent of total $\mathrm{m}^{3} \mathrm{ha}^{-1}$ ) and treatment (Int'l 1/4" Rule, following Gevorkiantz and Olsen (1955)) from 1978 - 2018. Volumes derived from entire-treatment unit removals. Conversion from board feet to cubic meters following Winn et al. (2020)

Table 2. 4 Comparison of MFV and periodic return from first two decades after sustainable stand structure was assumed at the Ford Forest study, and from the past three decades, with sawlog products valued at price in 2018 dollars. Discount rates of $2 \%$ and $4 \%$ are shown.

Table 2. 5 Initial 1956 pre-treatment relative species abundance (\%) and total change to pre-harvest 2018, for trees $>12.6 \mathrm{~cm}$ dbh, in 1956 and 2018 .

Table 3.1 Argonne EF average dbh $(\mathrm{cm})$ in 1951 (pre-treatment), 1952 (posttreatment), 2016 (4 years post-treatment), and average increase in diameter of individual trees $\geq 11.4 \mathrm{~cm}$ dbh from 1952 - 2016. In the DL18 treatment there were no survivor trees for that time period. Standard error in parentheses, $n=$ 15 . Means in a column followed by the same letter are not significantly different, $p<0.05$.

Table 3.2 For trees $>24 \mathrm{~cm}$ dbh at the Argonne EF, average merchantable height by number of 4.88-meter logs in 1972 and 2016. Standard error in parentheses, $n$ $=15$. Means in a column followed by the same letter are not significantly different, $\mathrm{p}<0.05$.

Table 3.3 Average annual dry factory grade sawn lumber yield since 1972 (estimated following Hanks (1976), $\mathrm{m}^{3} \mathrm{ha}^{-1} \mathrm{yr}$ ) by grade at the Argonne EF. Grade $1 \mathrm{C}+$ includes selects and better. Within each column values with the same letter are not significantly different, $p<0.05, n=15$. Conversion to cubic meters following Winn et al. (2020). 
Table 3.4 Argonne EF residual sawtimber volumes ( $\mathrm{m}^{3} \mathrm{ha}^{-1}$, Intl. 1/4" rule) estimated by number of logs following Gevorkiantz and Olsen (1955) for trees $>24 \mathrm{~cm}$ dbh. In 2002 merchantable height was not measured for the DL18 and crop tree treatments, so volume could not be estimated using Gevorkiantz and Olsen (1955). Conversion to cubic meters following Winn et al. (2020).......37

Table 3.5 Financial analysis of Argonne EF treatments, with potential dry factory grade lumber yields valued at price in current 2018 dollars. Present worth is discounted to study start in 1952.

Table 3.6 For trees $>24 \mathrm{~cm}$ dbh at the Argonne EF, average tree grades in 1972 and 2016, and average increase in grade of individual trees from 1972 - 2016. Grade scale from Hanks (1976), sawtimber grades 1-3 with below grade assigned a value of 4 . In the DL18 treatment there were no survivor trees from 1972 to 2016. Standard error in parentheses, $n=15$. Means in a column followed by the same letter are not significantly different, $p<0.05$.

Table 3.7 For trees $>24 \mathrm{~cm}$ dbh at the Argonne EF, average proportion of trees in each grade as measured in 2016, following Hanks (1976).

Table 3.8 Relative species abundance and diversity for trees $>11.4 \mathrm{~cm} \mathrm{dbh}$ at the Argonne EF, pre-treatment in 1951 and pre-harvest in 2011.

Table 3.9 Mean squares for analysis of variance of diameter, merchantable height, grade, grade proportions, annual ingrowth, and annual mortality at the Argonne EF. $*=$ significance at $\mathrm{p}<0.05, * *=$ significance at $\mathrm{p}<0.01, * * *$ significant at $\mathrm{p}<0.001, \mathrm{~ns}=$ not significant.

Table A.2.1 Summary Information 


\section{Author Contribution Statement}

Chapter 2: Six Decades of Financial Returns and Stand Dynamics in The Ford Forest Cutting Methods Study is currently under review for publication in the peer-reviewed journal Forest Science. Maeve Draper designed and completed the analysis, collected data, compiled historic data, and wrote the original manuscript draft. Robert Froese contributed to data acquisition, writing, and editing the manuscript.

Chapter 3: Six Decades of Financial Returns and Stand Dynamics in the Argonne Experimental Forest Cutting Methods Study is planned for submission to a peer-reviewed journal in the near future. Maeve Draper designed and completed the analysis, compiled historic data, and wrote the original manuscript draft. Christel Kern contributed to data acquisition, writing, and editing the manuscript. Robert Froese contributed to writing and editing the manuscript. Yvette Dickinson contributed to editing the manuscript. 


\section{Acknowledgements}

First and foremost, I would like to thank Dr. Robert Froese for his invaluable insight, knowledge, and support in all aspects of my grad school journey.

Many thanks to Dr. Christel Kern for her enthusiasm, support, and contributions, to Dr. Yvette Dickinson for her input into this thesis, and to Jim Schmierer for his help with data collection and willingness to share his knowledge of the Ford Forest.

Thank you to the members of Lab 135 for making each day at the office more enjoyable, through early mornings and late nights alike, and especially to Heidi and Ian for all of their fieldwork assistance and expertise.

For funding, I would like to recognize the support from Michigan Sustainable Forestry Initiative Implementation Committee, Wisconsin Sustainable Forestry Initiative Implementation Committee through the USDA Forest Service, and Michigan Technological University College of Forest Resources and Environmental Science. Lastly, to my family; Tim, thank you for always being there for me, from all of my complaints to all of my successes. Mom, Dad, and Breandan, it could go without saying that I wouldn't be where I am without you. 


\begin{abstract}
Common partial cutting management methods in Lake States hardwoods include both selection management and diameter-limit cuttings. Single-tree selection in particular is a widely prescribed silvicultural system in northern hardwoods and has an established history of use throughout the entire range of the forest type. Using data from two historic silvicultural studies, long-term comparison of single-tree selection methods and other partial cutting practices in northern hardwoods reveals that single-tree selection to higher residual basal areas, as widely applied in Great Lakes northern hardwood forests, is inferior using financial and volume yield criteria. Alternatives that remove more of the larger trees appear to increase regeneration and harvested tree quality over time, which in turn drives financial performance. However, treatments with extremely high volume removals perform poorly against all others and have few, if any, redeeming financial, silvicultural, or ecological qualities. As applied in the Lake States, most single-tree selection follows the Arbogast (1957) guide, and the implementation of alternatives to this may provide greater financial returns and higher average quality while also having implications on regeneration and long-term sustainability.
\end{abstract}




\section{Introduction}

Single-tree selection is an important and widely used forest management method in northern hardwoods (Kern et al. 2014; Pond et al. 2014). Selection management, in addition to other partial cutting methods, was first considered for use in the United States as an alternative to the clearcutting that was prevalent throughout the late $19^{\text {th }}$ century (Kenefic and Kern 2013; O'Hara 2002). Studies testing the applicability of several different partial cutting methods in northern hardwoods were thus instituted in the Lake States to investigate the potential of such methods (Eyre and Zillgitt 1953; Niese et al. 1995; Reed et al. 1986). The first of these was installed at the Dukes Experimental Forest near Marquette, MI, in 1926; subsequent results from this study led to the publishing of timber marking guide that is still widely influential today (Arbogast 1957; Pond et al. 2014). Instituted in part to expand on findings from the Dukes study, two other similar studies were set up in the region in the following decades: a study at the Argonne Experimental Forest in northern Wisconsin, and one at the Ford Forest owned and operated by Michigan Technological University in Alberta, MI.

These two studies have been consistently maintained in Lake States northern hardwoods for over 60 years. Both studies were begun on previously impacted second growth forests, however, the Argonne study was begun on even-aged second growth forest, while the Ford Forest study was uneven-aged at study commencement (Previant 2015; Stoeckler 1955). Both studies have been maintained over time, with data collection and harvesting occurring on regular bases and thus allowing for a thorough evaluation of the long-term consequences of silvicultural alternatives. Since the establishment of these silvicultural experiments, three different financial analyses have been published based on data collected from the studies, and the accompanying literature has consistently mentioned the need for a continuation of the studies and accompanying further analysis (Erikson et al. 1990; Niese et al. 1995; Reed et al. 1986). These previous analyses also focus on stand structure as well as characteristics such as species composition, quality, and volume changes through time in various partial cutting treatments including diameter-limit cuts, crop-tree treatments, and single-tree selection management. 
There are both benefits and drawbacks that come to light through evaluation of these various partial cutting methods. Selection silviculture, at this point in time, has a long history of use and is known to produce sustained yield and high quality trees in northern hardwoods forest (Nyland 2016), but there have been recent disquisitions on its sustainability due to concerns about a lack of regeneration and reduction in overstory and structural diversity (Angers et al. 2005; Gronewold et al. 2010; Neuendorff 2007). Detractors critiquing diameter-limit treatments consistently mention the lack of tending in residual size classes, and the potential dysgenic effects that may result from repeated removal of more vigorous, faster-growing trees (Kenefic et al. 2005, Kenefic and Nyland 2005, Fajvan 2006, Buongiorno et al. 2000, Hawley et al. 2005, Howe 1989, Nyland 1988, O'Hara 2002). However, some studies have found sustained volume yield, high financial return, and greater overstory species diversity after long-term application of diameter-limit cuts (Smith and Miller 1987; Buongiorno et al. 2000), and that single-tree selection systems reducing basal area further than traditionally recommended have produced higher overstory species diversity and better financial performance (Erickson et al. 1990; Niese and Strong 1992). The existence of such possible advantages and disadvantages in these types of partial cutting management show the need for comparisons of various management methods, including these and other partial cutting methods such as thinning and improvement treatments. The long-term nature of the Ford Forest and Argonne Experimental Forest cutting methods studies facilitate such comparisons, which are important to identify trends through time, and have the potential to inform management decisions far into the future.

This thesis is divided into two chapters. The first re-examines results from the first three decades of the Ford Forest study in the context of 30 years of additional data collection and management. The second chapter re-visits the Argonne study to complete a new financial analysis, and to examine the data collected in the 25 years since publications by Niese et al. (1995) and Strong et al. (1995). The main goal is to examine yield, structure, grade improvements, and financial performance through time, and to identify factors that may explain observed differences within and across treatments, particularly since the most recent analyses. 


\section{Six Decades of Financial Returns and Stand Dynamics in the Ford Forest Cutting Methods Study}

\subsection{Introduction}

Single-tree selection is a silvicultural system that is widely prescribed in Lake States northern hardwoods and has an established history of use throughout the entire range of the forest type (Kern et al. 2014; Pond et al. 2014). At the start of the $20^{\text {th }}$ century, partial cutting methods were well established in Europe, and questions had begun to arise about their use in the United States (Kenefic and Kern 2013; O'Hara 2002). To help answer these questions, studies testing the viability of several different partial cutting methods in northern hardwoods were instituted in the Lake States (Eyre and Zillgitt 1953; Niese et al. 1995; Reed et al. 1986). And indeed, initial research in the Lake States showed that singletree selection in uneven-aged northern hardwoods could shape and maintain an economically and ecologically productive forest (Eyre and Zillgitt 1953; Erdmann and Oberg 1973). The management goals of stands under single-tree selection usually include high quality sawtimber and a balanced diameter distribution (Nyland 1998; Tubbs 1977a). To help achieve these goals, analysis of stand structure and financial returns are useful evaluations that can provide important information about quality and value.

Quality and volume directly affect financial gain and consequently also influence management decisions. Previous long-term studies evaluating silvicultural treatments in northern hardwoods have found that single-tree selection can increase quality and volume growth (Johnson 1984; Leak and Sendak 2002). The monetary value of most hardwoods is greatly affected by wood quality, and so managing to improve quality and reduce logging damage in northern hardwoods is important for improving financial yield; with an increase in quality and grade, the monetary value of a tree sharply increases (Miller 1991; Wiedenbeck and Smith 2018). Increases in quality resulting from single-tree selection in hardwoods have resulted in higher financial yield (Orr et al. 1994; Schuler et al. 2017). In a simulation in northern hardwoods, Bohn et al. (2011) found that initial harvest volumes will be greatest with diameter-limit cuts but may be later outperformed by single-tree 
selection with up to $20-40 \%$ greater volumes per harvest. A simulation by Nyland (2005) also found that selection treatments will generate higher long-term revenues. However, in several long-term studies, diameter-limit cuts resulted in the greater financial returns than selection (Buongiorno et al. 2000; Erickson et al. 1990; Miller 1993; Reed et al. 1986; Smith and Miller 1987). A recent study in northern hardwoods also found that single-tree selection cuts did not greatly increase growth or survival in residual trees (Moreau 2019). This past research shows the value of long-term studies to test hypotheses based on simulation, while also exhibiting that there can be successful growth under various different partial cutting management regimes. Thus, there is a need to evaluate the longterm success and applicability of different management regimes over many harvest entries, using both financial and ecological factors (Erickson et al. 1990).

Data from the cutting methods study at the Ford Forest present an exceptional opportunity to evaluate long-term consequences from silvicultural alternatives in northern hardwoods. The study was established in 1956, with an objective of evaluating stand development and financial benefit under different partial cutting methods through time (Bourdo 1957). Methods tested include single-tree selection, cutting above a diameter limit, a "light improvement" cut emphasizing residual quality over structure, and an unmanaged control. Although the design uses single replicates of each cutting method, this case study and associated long-term dataset have generated results that increase the evidence base upon which solutions to management problems can be formed. An important precedent can be found in the historic northern hardwoods cutting methods study at the Dukes Experimental Forest in the Upper Peninsula of Michigan. While also unreplicated, it is nevertheless the foundation for the renowned Eyre and Zillgit (1953) publication, on which the influential and widely prescribed Arbogast (1957) marking guide for northern hardwoods is directly based. The cutting methods study at the Ford Forest was designed in consultation with Carl Arbogast with the intent to establish selection treatments similar to those at the Dukes Experimental Forest (Kern et al. 2014). Unfortunately, there are problems with the Dukes dataset including gaps in harvest cycle entries and damage to the control, making other long-term studies such as this one, that have been consistently 
maintained and monitored in upper Great Lakes northern hardwoods forest, even more consequential.

Two important publications have resulted from the cutting methods study at the Ford Forest: Reed et al. (1986) and Erickson et al. (1990), which present 22 and 32-year results. In addition to examining yield and quality improvement, these studies contrast financial performance of the various treatments in terms of discounted net revenues to the initiation of the study (in 1956), and in terms of a long-term sequence of repeatable yields once stand structure has stabilized under several harvest cycles sensu Rideout (1985). These values are influenced by the interest rate chosen and the cost terms included, but often when comparing treatment performance, costs do not need to be included because the end result is a decision whether or not to take management action (Martin and Leudeke 1989). These alternative approaches embody two perspectives: one of the landowner considering near-term financial implications of alternatives, and the other a long-term perspective on the continuous yield and financial return. Given a defining feature of selection silviculture is continuous stocking, when assessing the long-term consequences of alternative methods, the return under repeated cycles of the same treatment is arguably much more relevant than return from initial conversion.

To evaluate long-term performance, both Reed et al. (1986) and Erickson et al. (1990) assumed that stand structure and periodic yield had stabilized 20-30 years after the initial conversion. A key conclusion from both analyses was the superiority of diameterlimit methods over single-tree selection, based on financial criteria, particularly for a diameter limit of $41 \mathrm{~cm}$ in contrast to larger or smaller alternatives. These early studies also suggest that careful application of the selection system led to improvements in the grade of residual standing trees, in comparison to both diameter-limit treatments and an untreated control. While some shifts in ranking among the treatments occurred in the 10year interval between the two analyses, both questioned whether increases in grade under the selection treatment would eventually lead to an increase in return that would surpass those of the diameter-limit cuts, a result forecast by Bohn et al. (2011) and Nyland (2005) using models. These questions can only be addressed empirically following an extended 
study period, and as Reed et al. (1986) note, they are "of utmost importance to small, nonindustrial ownerships."

The overall goal of this analysis was to re-examine this silvicultural experiment (Erikson et al. 1990; Reed et al. 1986), with an emphasis on changes that have accumulated over the second 30 years of the study. Specific objectives included: (1) to examine stability of yield and structure within and across treatments since the most recent analysis, (2) to explore the hypothesis that further improvement in standing tree grade would occur in single-tree selection but not diameter-limit treatments, (3) to revisit the hypothesis that single-tree selection treatments could "catch up" to the diameter-limit treatments on financial criteria, and (4) to identify factors that may explain observed differences in yield, structure, and financial performance with time, which may be explored in future research.

\subsection{Methods}

\subsubsection{Site description}

The study is located at the Ford Forest in Baraga County, MI $\left(46.66^{\circ} \mathrm{N}, 88.51^{\circ} \mathrm{W}\right)$ which is a research forest owned and operated by Michigan Technological University. The 26.3 ha study area is uniform in soils and topography, and as a consequence is also uniform in ecological habitat type and site productivity. Soils are classified as Alouez gravelly coarse sandy loams, slopes 0-6\%, habitat type ATD (Acer-Tsuga-Dryopteris; Burger and Kotar 2003), and sugar maple site index is 19-21 m base age 50 (Soil Conserv. Serv. 1988). Circa 1898 the white pine in the area was removed from what had initially been a pinehardwood forest, and subsequent selective logging in the early 1900 s removed over $70 \%$ of the merchantable sawtimber (Bourdo 1957; Reed et al. 1986). In 1956 the Cutting Methods Study was begun on the residual northern hardwoods forest, which was an unevenaged sugar maple-dominated mix of regeneration and remnant trees from previous harvests; treatment units were uneven-aged to begin with, with overstory sugar maple in the control ranging from 38.5 to 252.5 years old as measured in 2014, and after 52-years of management, the age structure of all six treatments was similar (Previant 2015). 
The study area was divided into eight different silvicultural treatments and a control, ranging from 1.2 to 5.7 ha in area, with an objective of showing the effects of various cutting methods on stand development and yield. Treatments are (i) $13 \mathrm{~cm}$ diameter-limit (DL13), (ii) $30 \mathrm{~cm}$ diameter-limit (DL30), (iii) $41 \mathrm{~cm}$ diameter-limit (DL41), (iv) $56 \mathrm{~cm}$ diameter-limit (DL56), (v) single-tree selection system cut to $21 \mathrm{~m}^{2} \mathrm{ha}^{-1}$ residual basal area (STS21), (vi) single-tree selection system cut to $16 \mathrm{~m}^{2} \mathrm{ha}^{-1}$ residual basal area (16 STS), (vii) single-tree selection system cut to $11 \mathrm{~m}^{2} \mathrm{ha}^{-1}$ residual basal area (STS11), (viii) light improvement (LI), and (ix) control (Bourdo 1957). The light improvement treatment is defined as a $15-16 \mathrm{~m}^{2} \mathrm{ha}^{-1}$ residual basal area treatment based on increasing quality. In the selection treatments, a balanced diameter distribution with a $q$-value of 1.3 and a maximum tree size of $61 \mathrm{~cm}$ was a goal for each harvest entry. Selection treatment guidelines followed Arbogast (1957) and emphasized removing trees that had poor quality or vigor, were high risk or cull, lacked the potential for improvement, or impeded the growth of other highquality trees. In diameter-limit cuts, harvesting was confined to trees above the diameter limit with no tending in the residual stand.

From 1956 to present day the treatments have been harvested on 10-year cycles, though some were cut only when volume growth had been sufficient to make an operational-scale harvest feasible. Efforts were consistently made throughout the study period to reduce site damage and potential harm to residual trees, although growth and survival of individual trees is primarily related to the competitive pre-harvest environment when compared to potential machinery damage (Moreau 2019). Skid trails present within compartments were re-used and crews were usually local, familiar with the area, and in regular contact with the supervising forester.

\subsubsection{Measurements}

Within each treatment unit, a single 0.4 ha plot was established and divided into 10 equal-area subplots, with a preharvest inventory conducted in 1956. The following measurements were collected for trees greater than $12.6 \mathrm{~cm} \mathrm{dbh:} \mathrm{species,} \mathrm{dbh,}$ merchantable sawlog height to a $25.4 \mathrm{~cm}$ outside bark minimum diameter, gross and net 
volume (International 1/4" rule) for trees greater than $28 \mathrm{~cm} \mathrm{dbh}$, cull percent, and butt-log tree grade. The same measurements were also collected prior to harvests in 1957, 1968, 1978, 1988, and 1998. Prior to harvest in 2008, slightly different measurements were collected. These included, for trees greater than $12.6 \mathrm{~cm}$ dbh: species, dbh, location within plot, total height, height to live, merchantable height, and percent soundness and grade for sawtimber trees. Prior to harvest in 2018, measurements collected were species, dbh, number of 2.4-meter (8-ft) sawlogs and 2.4-meter pulp sticks, and percent soundness and grade for sawtimber trees. Standing tree grades were estimated following the USDA Forest Service Timber Management Field Book Region 9 (USDA Forest Service 2008) and volumes were estimated using Gevorkiantz and Olsen (1955).

At each harvest entry, the harvest removal from the entire treatment unit was stacked and scaled by grade onsite. Logs were graded to the standards of the Northern Hardwood and Pine Manufacturers Association prior to 1988, and after to the standards of Timber Producers Association of Michigan and Wisconsin. These data were standardized to a per-unit-area basis for financial analyses, and volume was converted from board feet to cubic meters following Winn et al. (2020).

\subsubsection{Growth and yield}

Estimated butt-log grade for sawtimber size class trees was used to indicate stand quality improvement over time. Post-harvest standing volumes and cumulative volume removals by grade were used to compare outcomes from the different treatments. The effect of treatment on stand structure was evaluated by comparing pre-study diameter distributions from 1956, pre-harvest diameter distributions from halfway through the study in 1998, and the most recent pre-harvest diameter distributions from 2018 (Pond and Froese 2015). Unfortunately, pre-harvest stand structure data from 1988 were not available, so 1998 data were used instead.

Species abundance was reported to evaluate changes in overstory (trees $>12.6 \mathrm{~cm}$

dbh) species composition since 1956. Pre-treatment 1956 values were taken directly from 
the establishment report (Bourdo 1957). Pre-harvest 2018 values were found using individual tree data. All values are reported as a percentage of stems per measurement area relative to each species, for each treatment.

\subsubsection{Financial analysis}

In this study, the managed forest value (MFV) was emphasized in financial analyses, following Rideout (1985). Rideout (1985) uses an analysis that looks at the managed forest value in conjunction with the net present value, in order to evaluate the return from conversion as well as an infinite series of repeatable returns once the stand has reached 'sustainable stand structure', where all future harvests will produce similar cash flow each cutting cycle. MFV is the discounted value of the sum of an infinite series of harvests, assuming a stable structure and reliable estimate of future volume removals by grade, and is intended to represent the long-term applicability of a silvicultural system. Two assumptions about sustainable stand structure were evaluated: (1) that it was reached in 1978 after two entries, following Reed et al. (1986) and Erickson et al. (1990), and (2) in 1998, relying instead on the most recent 30 years of results since Erickson (1990). Financial performance was compared between each treatment and the control using discount rates of $2 \%$ and 4\%. Total revenue accumulated since 1978 was also evaluated at these same discount rates.

In both MFV and total revenue calculations, 2018 dollars were used to facilitate comparison. While MFV for 1998-2018 uses current 2018 prices, the price structure used in total revenue calculations was that of regional historic prices from each year of harvest adjusted to a common 2018 basis using the producer price index for lumber and wood

products (U.S. Bureau of Labor Statistics). Actual prices were used where available from timber sale records, augmented where necessary by historic pricing from Ulrich (1983) and Michigan DNR stumpage reports. The MFV values for 1978-1988, taken directly from Erickson et al. (1990), were also adjusted to a 2018 basis. No cost factors were introduced into the analysis due to the intent to compare relative, not absolute, measures of financial returns between treatments. 


\subsection{Results}

\subsubsection{Quality}

The grade distribution for pre-harvest standing tree volume continually improved from 1968 through 2018 in the LI and the STS treatments, with the most notable change being a decline in the proportion of non-merchantable and sharp increase in grade 1 (Figure 2. 1). The greatest increase in percentage of grade 1 trees since 1968 of the selection treatments was in the STS11 (increase by 283\%) and by 2018 the proportion of grade 1 had increased from about $15-20 \%$ to $30-50 \%$ in all STS treatments. In contrast, while the grade distribution improved somewhat between 1968 and 1988 in the DL treatments, there has been little change through 2018, and the proportion of grade 1 actually fell in all but the DL56 treatment. In 2018, the STS11 had the greatest proportion of grade 1 among the STS treatments, and the DL41 among the DL treatments. Still, over the entire duration of the study, grade 1 percentages in all treatments have increased, excluding the DL30 and DL13.

Notably, by 2018 only the LI and STS11 had greater grade 1 percentages than the control. Since grade is strongly determined by tree size, the grade increase in the control with time likely reflects an increase in mean tree size, and thus comparisons may be confounded with the absence of treatment. To isolate treatment differences, grade proportion was re-calculated for only trees $\geq 46 \mathrm{~cm} \mathrm{dbh}$; this dbh was chosen because under the log grading rules used all trees $46 \mathrm{~cm}$ and above had equally the least stringent requirements to meet grade 1 criteria (smallest minimum length per clear cutting and greatest maximum number of clear cuts per face). Under this criterion, in 2018 all STS treatments and the LI had a larger proportion grade 1 standing tree volume than the control (Table 2. 1). For trees $\geq 30 \mathrm{~cm}$ dbh and $\leq 46 \mathrm{~cm} \mathrm{dbh}$, that is, trees likely to increase in grade as diameter increases, the DL41 had the highest number of grade 2 trees both pre-and postharvest. 


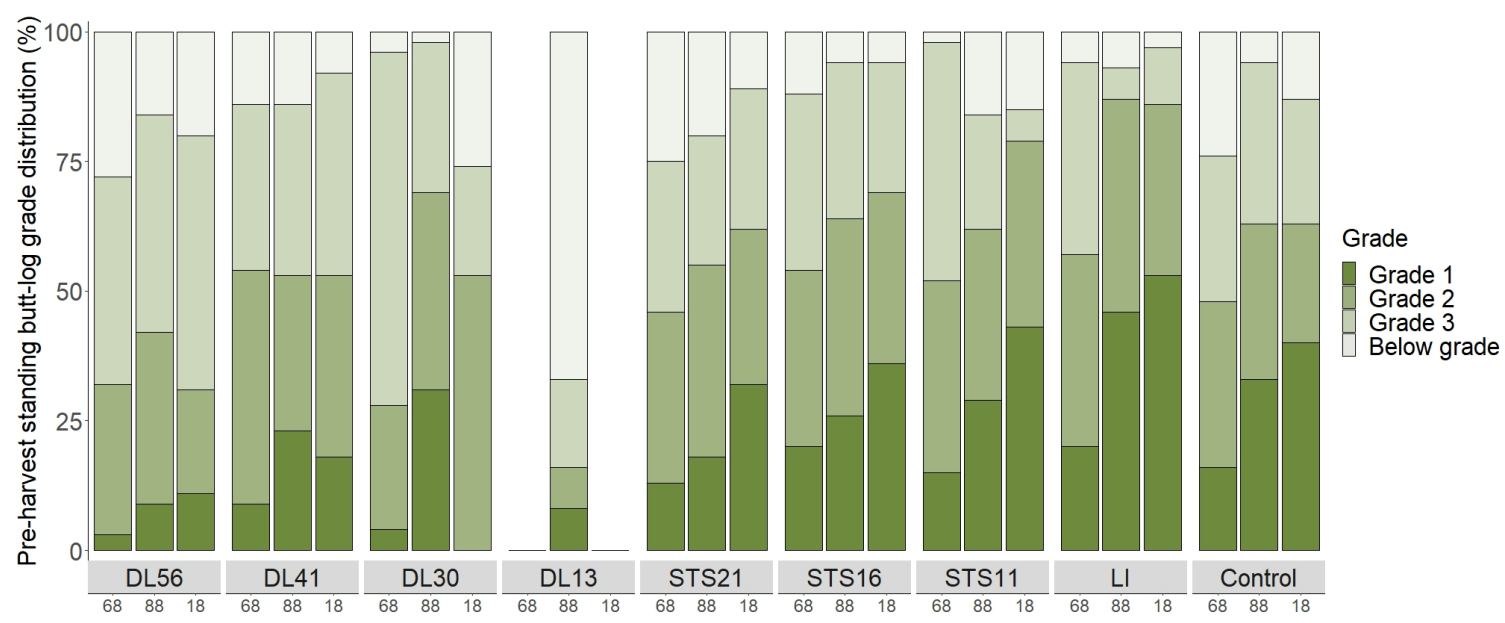

Figure 2. 1 Ford Forest pre-harvest standing tree butt log grade distribution (\%) by grade as measured in 1968, 1988, and 2018 in 0.4-hectare measurement units, for trees $>28 \mathrm{~cm}$ dbh (Erickson et al. 1990). Non-merchantable (nm) class consists of trees $>28 \mathrm{~cm}$ dbh without any merchantable volume, as well as cull trees. Grade 1 includes grade 1 and better.

Table 2. 1 Ford Forest grade distribution (\%) in 2018 by size classes corresponding to $\log$ grading rules threshold diameters. Grade 1 includes grade 1 and better.

\begin{tabular}{cccccc|cccc}
\hline & Size & \multicolumn{4}{c}{$30-45 \mathrm{~cm}$} & \multicolumn{4}{c}{$>45 \mathrm{~cm}$} \\
\cline { 3 - 10 } & Grade & 1 & 2 & 3 & $\mathrm{~nm}$ & 1 & 2 & 3 & $\mathrm{~nm}$ \\
\hline \multirow{6}{*}{ Pre- } & DL56 & 8 & 21 & 56 & 15 & 21 & 25 & 33 & 21 \\
& DL41 & 22 & 40 & 32 & 6 & - & - & - & - \\
harvest & DL30 & 67 & 33 & - & - & - & - & - & - \\
& DL13 & - & - & - & - & - & - & - & - \\
& STS21 & 11 & 41 & 60 & 18 & 73 & 14 & 13 & - \\
& STS16 & 26 & 39 & 32 & 3 & 69 & 23 & 8 & - \\
& STS11 & 30 & 55 & 10 & 5 & 89 & 11 & - & - \\
& LI & 42 & 39 & 15 & 4 & 81 & 19 & - & - \\
& Control & 18 & 36 & 40 & 6 & 65 & 17 & 11 & 6 \\
\hline & DL56 & 8 & 22 & 59 & 11 & 22 & 28 & 39 & 11 \\
& DL41 & 3 & 57 & 37 & 3 & - & - & - & - \\
& DL30 & - & - & - & - & - & - & - & - \\
Post- & DL13 & - & - & - & - & - & - & - & - \\
harvest & STS21 & 11 & 41 & 60 & 18 & 73 & 14 & 13 & - \\
& STS16 & 28 & 44 & 28 & - & 80 & 20 & - & - \\
& STS11 & 31 & 56 & 13 & - & 86 & 14 & - & - \\
& LI & 42 & 42 & 12 & 4 & 80 & 20 & - & - \\
& Control & 18 & 36 & 40 & 6 & 65 & 17 & 11 & 6 \\
\hline
\end{tabular}




\subsubsection{Volume and yield}

Standing sawtimber volumes through time have persisted as expected, with the DL56, DL41, and DL30 treatments each retaining more volume than the next smaller limit, respectively (Table 2. 2, Figure 2. 2). Similarly, the residual volumes of the selection treatments line up as STS21 > STS16 > STS11. Since 1988 the DL41 treatment consistently had the greatest sawtimber volume growth, with an average of $2.92 \mathrm{~m}^{3} \mathrm{ha}^{-1}$ per year (Table 2. 2). Prior to harvest in 2018, all treatments except for the harshest diameter-limit (DL30 and DL13) cuts had greater per ha volumes than in 1956.

While sawtimber volume yields since 1978 for the selection treatments follow the expected pattern of volume from STS11 $>$ STS16 $>$ STS2 1 treatment, the DL41 treatment produced greater yields than the DL30 or DL56 (Figure 2. 3, Table 2. 3). The DL41 treatment had not only the greatest overall removal volume with an average of $2.2 \mathrm{~m}^{3} \mathrm{ha}^{-1}$ per year, but the greatest total volumes of grade 1 and grade 2 sawtimber produced since sustainable stand structure was reached in 1978. The grades for these harvested volumes are more accurate than those estimated for standing trees.

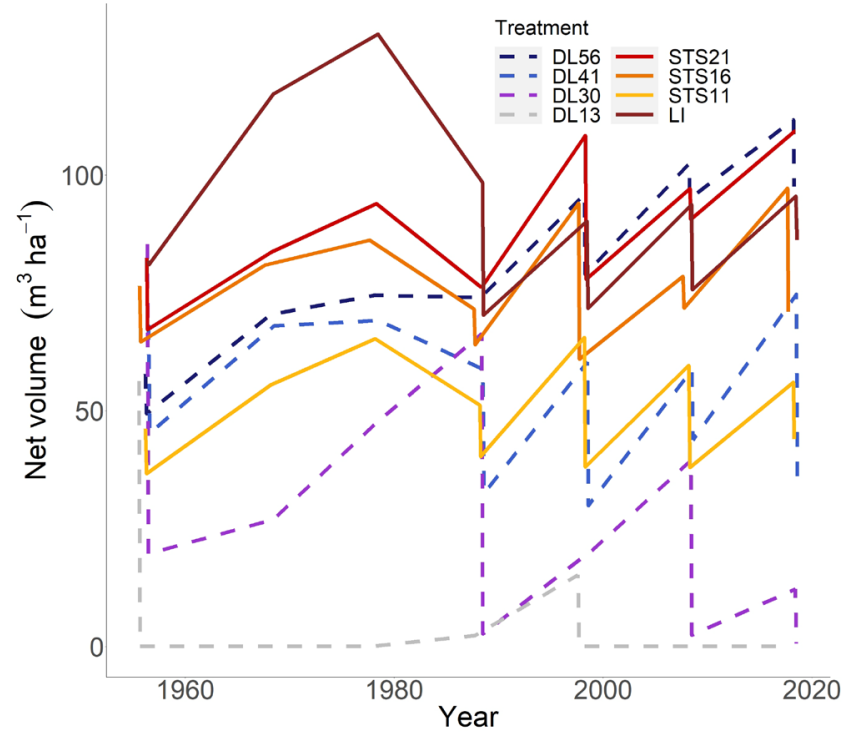

Figure 2. 2 Net residual standing sawtimber volume $\left(\mathrm{m}^{3} \mathrm{ha}^{-1}\right.$, from 0.4 -ha measurement units) over the 62-year study period (Int' 1 1/4" Rule, following Gevorkiantz and Olsen (1955)) at the Ford Forest. Conversion from board feet to cubic meters following Winn et al. (2020). Data not available post-harvest for 1968 and 1978. 
Table 2. 2 Net residual standing sawtimber volume $\left(\mathrm{m}^{3} \mathrm{ha}^{-1}\right.$, from 0.4 -ha measurement units) over the 62-year study period (Int'1 1/4" Rule, following Gevorkiantz and Olsen (1955)) at the Ford Forest. Conversion from board feet to cubic meters following Winn et al. (2020). Post-harvest values are shaded in grey; data are not available post-harvest for 1968 and 1978.

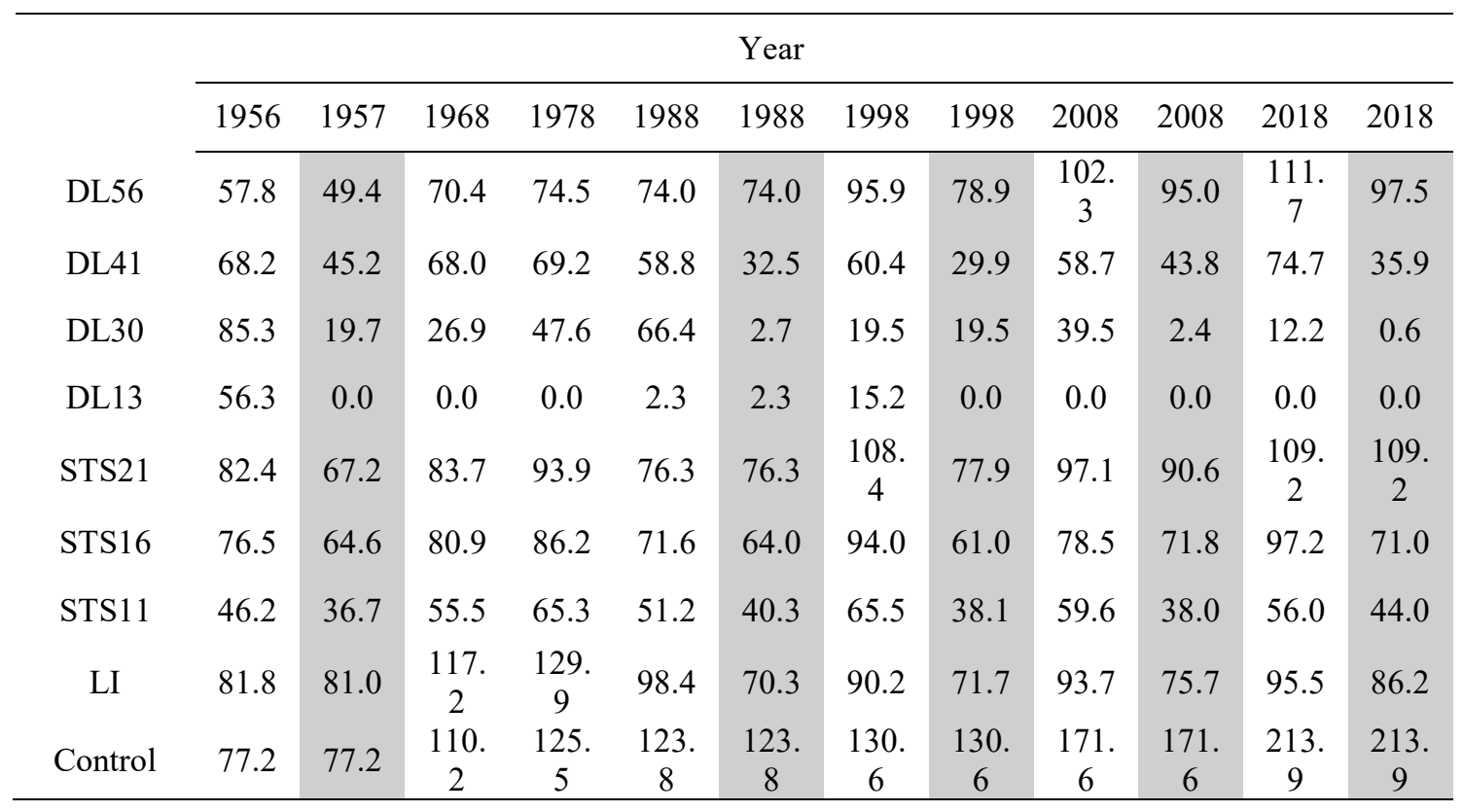

Table 2. 3 Ford Forest net scaled harvested sawtimber volume by grade (percent of total $\mathrm{m}^{3} \mathrm{ha}^{-1}$ ) and treatment (Int'1 1/4" Rule, following Gevorkiantz and Olsen (1955)) from 1978 - 2018. Volumes derived from entire-treatment unit removals. Conversion from board feet to cubic meters following Winn et al. (2020).

\begin{tabular}{|c|c|c|c|c|c|c|c|c|c|}
\hline Year & & DL56 & DL41 & DL30 & DL13 & STS21 & STS16 & STS11 & LI \\
\hline \multirow{4}{*}{$\begin{array}{c}1978 \\
- \\
1988\end{array}$} & Grade $1^{a}(\%)$ & 31 & 33 & 26 & - & 29 & 13 & 16 & 23 \\
\hline & Grade $2(\%)$ & 38 & 35 & 46 & - & 41 & 33 & 37 & 52 \\
\hline & Grade $3(\%)$ & 31 & 32 & 28 & - & 30 & 54 & 47 & 25 \\
\hline & $\begin{array}{c}\text { Mean annual } \\
\left(\mathrm{m}^{3} \mathrm{ha}^{-1}\right)\end{array}$ & 0.3 & 2.7 & 2.7 & - & 0.9 & 0.9 & 1.6 & 2.1 \\
\hline \multirow{4}{*}{$\begin{array}{c}1998 \\
- \\
2018\end{array}$} & Grade $1^{\mathrm{a}}(\%)$ & 41 & 41 & 7 & 08 & 43 & 31 & 35 & 51 \\
\hline & Grade $2(\%)$ & 26 & 30 & 18 & 59 & 36 & 44 & 35 & 16 \\
\hline & Grade $3(\%)$ & 33 & 29 & 75 & 33 & 21 & 25 & 30 & 33 \\
\hline & $\begin{array}{c}\text { Mean annual } \\
\left(\mathrm{m}^{3} \mathrm{ha}^{-1}\right)\end{array}$ & 1.1 & 1.9 & 0.8 & 0.4 & 1.2 & 1.6 & 1.8 & 0.9 \\
\hline \multicolumn{2}{|c|}{$\begin{array}{l}\text { Total mean annual } \\
\qquad\left(\mathrm{m}^{3} \mathrm{ha}^{-1}\right)\end{array}$} & 0.8 & 2.2 & 1.6 & 0.2 & 1.1 & 1.3 & 1.7 & 1.4 \\
\hline
\end{tabular}

ancludes grade 1 and better. 

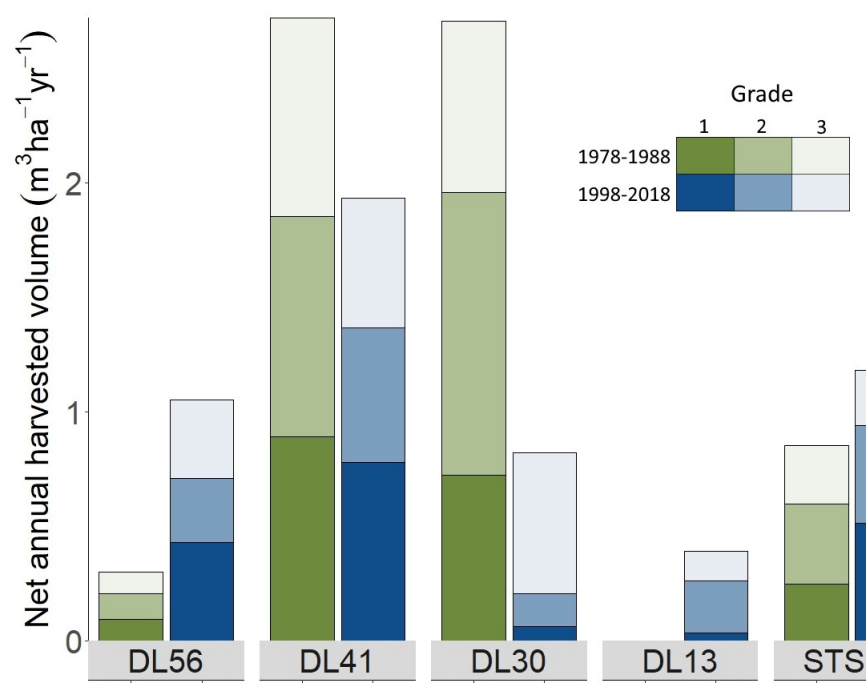

Figure 2. 3 Ford Forest net scaled harvested sawtimber volume by grade (percent of total $\mathrm{m}^{3} \mathrm{ha}^{-1}$ ) and treatment (Int'1 1/4" Rule, following Gevorkiantz and Olsen (1955)) from 1978 - 2018. Volumes derived from entire-treatment unit removals. Conversion from board feet to cubic meters following Winn et al. (2020).

\subsubsection{Financial returns}

Excluding 1957-1968, and thus the effects of initial stand conditions, the DL41, STS21, and LI perform best under MFV at a 4\% discount rate in the first half of the study (Erickson et al. 1990; Table 2. 4). Using only returns from previous three decades, the DL41 is still ranked first, but is followed instead by the STS11 and STS16 (Table 2. 4). Real sugar maple stumpage prices were higher in 2018 than 1988 (Wagner et al. 2019), resulting in greater dollar values for the 1998-2018 MFV and periodic return calculations.

Total discounted revenues since 1978, when sustainable stand structure was assumed to have been reached (Reed et al. 1986), show the rate at which different treatments have been accumulating revenue (Figure 2. 4). At all discount rates the DL41 is uniformly superior. Other treatments such as the STS11 and LI that have been cut each 10year harvest cycle also perform well, but still do not show a rate of revenue accumulation that has allowed them to equal or surpass the DL41. The STS11 and STS21 begin in 1978 with very similar revenue, but the STS11 rapidly surpasses the STS21 at all discount rates. The selection treatments, DL41, and DL30 have all been accumulating revenue at a greater rate than the DL56 and DL13 over the past three decades. 
Table 2. 4 Comparison of MFV and periodic return from first two decades after sustainable stand structure was assumed at the Ford Forest study, and from the past three decades, with sawlog products valued at price in 2018 dollars. Discount rates of $2 \%$ and $4 \%$ are shown.

\begin{tabular}{|c|c|c|c|c|c|c|c|c|c|}
\hline Period & Attribute & $\begin{array}{l}\mathrm{DL} \\
56\end{array}$ & $\begin{array}{c}\mathrm{DL} \\
41\end{array}$ & $\begin{array}{l}\mathrm{DL} \\
30\end{array}$ & $\begin{array}{c}\mathrm{DL} \\
13\end{array}$ & $\begin{array}{c}\text { STS } \\
21\end{array}$ & $\begin{array}{c}\text { STS } \\
16\end{array}$ & $\begin{array}{c}\text { STS } \\
11\end{array}$ & LI \\
\hline \multirow{5}{*}{$\begin{array}{l}1978- \\
1988^{\mathrm{a}}\end{array}$} & $\begin{array}{l}\text { Periodic Return } \\
\qquad\left(\$ \cdot \mathrm{ha}^{-1}\right)\end{array}$ & 133 & 566 & 1060 & 1060 & 261 & 191 & 250 & 525 \\
\hline & $\begin{array}{l}\text { Mean Treatment } \\
\text { Interval (years) }^{\mathrm{b}}\end{array}$ & 10 & 10 & 30 & 40 & 10 & 10 & 10 & 10 \\
\hline & $\begin{array}{c}\operatorname{MFV}\left(\$ \cdot h a^{-1}\right) \\
2 \%\end{array}$ & 609 & 2584 & 1306 & 878 & 1190 & 872 & 1142 & 2397 \\
\hline & $\begin{array}{c}\operatorname{MFV}\left(\$ \cdot h^{-1}\right) \\
4 \%\end{array}$ & 277 & 1177 & 472 & 279 & 1095 & 398 & 521 & 1093 \\
\hline & Ranking & 8 & 1 & 5 & 7 & 2 & 6 & 4 & 3 \\
\hline \multirow{6}{*}{$\begin{array}{l}1998- \\
2018\end{array}$} & $\begin{array}{c}\text { Periodic Return } \\
\left(\$ \cdot \mathrm{ha}^{-1}\right)\end{array}$ & 2051 & 2240 & 1159 & 1425 & 1880 & 1781 & 2005 & 1145 \\
\hline & $\begin{array}{l}\text { Mean Treatment } \\
\text { Interval (years) }\end{array}$ & 17 & 10 & 20 & 40 & 13 & 10 & 10 & 10 \\
\hline & $\begin{array}{c}\operatorname{MFV}\left(\$ \cdot h a^{-1}\right) \\
2 \%\end{array}$ & 5126 & 10228 & 2385 & 1180 & 6403 & 8134 & 9155 & 5227 \\
\hline & $\begin{array}{c}\operatorname{MFV}\left(\$ \cdot h^{-1}\right) \\
4 \%\end{array}$ & 2164 & 4664 & 973 & 375 & 2827 & 3709 & 4174 & 2384 \\
\hline & Ranking & 6 & 1 & 7 & 8 & 4 & 3 & 2 & 5 \\
\hline & $\Delta$ MFV rank & +2 & 0 & -2 & -1 & -2 & +3 & +2 & -2 \\
\hline
\end{tabular}

${ }^{a}$ Values from Erickson et al. 1990 adjusted to 2018 prices using the PPI for Lumber and Wood Products. Real sugar maple stumpage prices were higher in 2018 than in 1988 contributing to differences in value. ${ }^{\mathrm{b}}$ Treatment interval is the average of the cutting cycles lengths associated with each harvest by the end of the period, except for the DL13 where it is the interval between the only two harvests in entire study. 

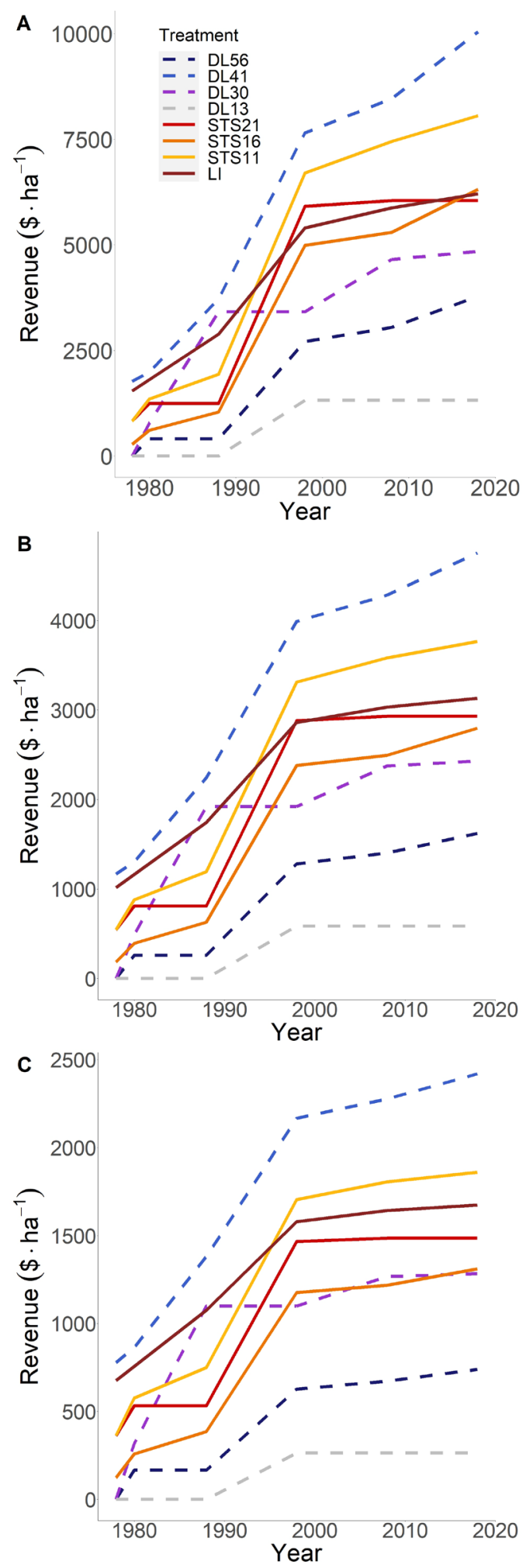

Figure 2. 4 Cumulative revenue since 1978 in 2018 dollars by treatment at the Ford Forest: (A) 0\% discount rate, (B) 2\% discount rate, and (C) 4\% discount rate. 


\subsubsection{Structure and density}

When this study began in 1956, the diameter distribution followed a reverse-J shape that was relatively homogenous across treatments (i.e., in pre-treatment condition; Figure 2. 5A). By 1998, differences in pre-harvest maximum diameter were clearly apparent among the DL treatments and the control, but less so among the STS treatments (Figure 2. 5B). Between 1998 and 2018 structure was relatively stable in the DL treatments, with a sharp drop in density at the relevant diameter limit. In contrast, structure in the STS treatments appears more variable within than between treatments, but appears to have become more stable and more closely approximating the original reverse-J shape in 2018 (Figure 2. 5B, C). Pre-harvest, in both 1998 and 2018, the DL30 and DL41 had the most trees in the pole and small sawtimber size classes, with the disparity between them and all other treatments growing larger with time. The 1998 and 2018 pre-harvest structures of the selection treatments can still be described as reverse-J, but stocking in the smallest diameter classes is much lower than that measured in 1956.

The DL30, DL41, and DL56 treatments have similar post-harvest basal areas to the STS11, STS16, and STS21 treatments, respectively (Figure 2. 6B). However, there is a clear difference in trees per hectare (TPH) between selection and diameter-limit treatments in that the diameter-limit treatments are associated with increasing stand density with time. For the past four harvest entries, these three diameter-limit treatments have had much higher post-harvest TPH than the single-tree selection treatments; even the DL56 treatment outperforms the selection treatments here. So, TPH has increased over time for the diameter-limit treatments while steadily decreasing for the selection treatments and control (Figure 2. 6A). This indicates the diameter-limit treatments are recruiting new trees, net of mortality and removals, whereas the selection treatments are not. The noticeable decline in post-harvest TPH without a corresponding decline in basal area (ideally kept at 11, 16, 21, and 15-16 $\mathrm{m}^{2} \mathrm{ha}^{-1}$ for the STS11, STS16, STS21, and LI treatments respectively) also indicates that growth in selection treatments is increasingly accumulating on larger diameter trees. 

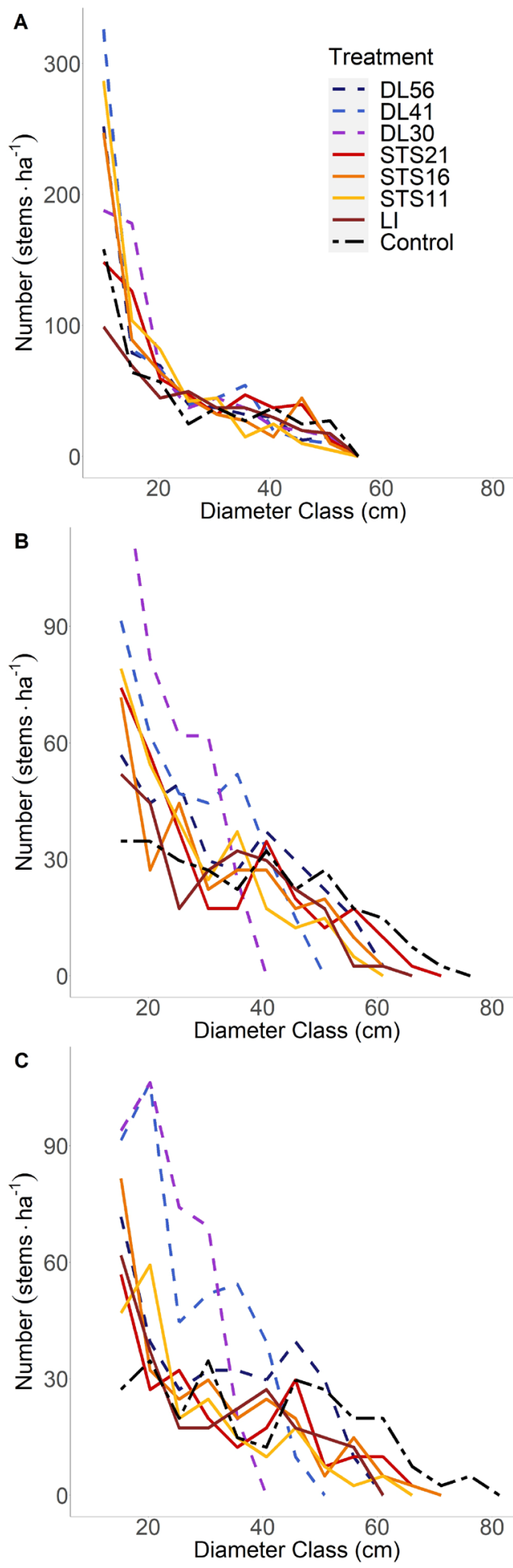

Figure 2. 5 Ford Forest: (A) Stand structure pre-harvest at study commencement in 1956 for trees $\geq 12.6 \mathrm{~cm}$ dbh. The $50 \mathrm{~cm}$ class contains all trees in larger diameter classes. (B) Stand structure pre-harvest in 1998 for trees $\geq 12.6 \mathrm{~cm} \mathrm{dbh}$. (C) Stand structure preharvest in 2018 for trees $\geq 12.6 \mathrm{~cm}$ dbh. 

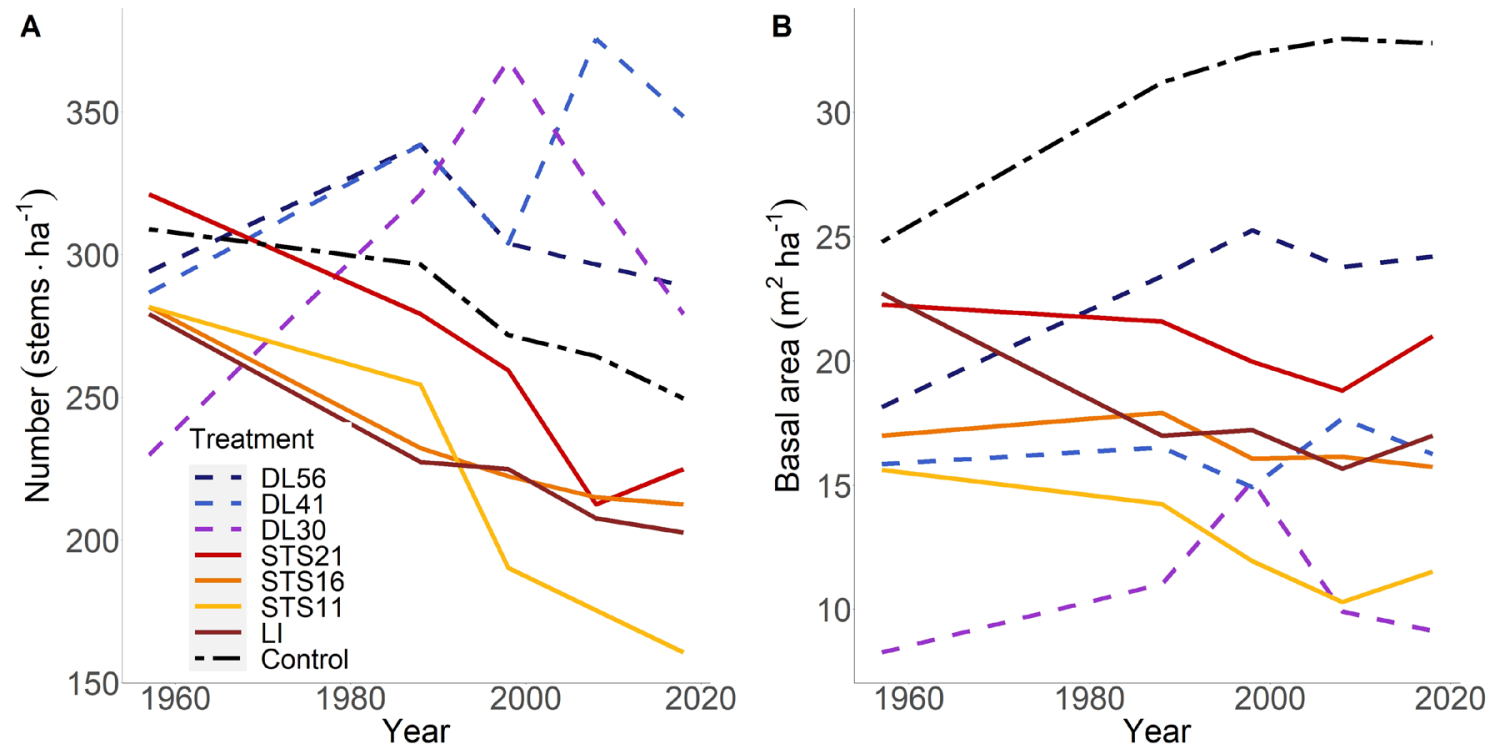

Figure 2. 6 Ford Forest post-harvest stand density over time for all treatments, excluding the $13 \mathrm{~cm}$ DL cut, in terms of (A) number of trees $\left(\mathrm{stems}^{\cdot} \mathrm{ha}^{-1}\right)$ and (B) basal area $\left(\mathrm{m}^{2} \cdot \mathrm{ha}^{-}\right.$ $\left.{ }^{1}\right)$. 


\subsubsection{Species composition}

Relative overstory species composition pre-treatment in 1956 was sugar maple dominated, with the STS21 having the lowest relative sugar maple abundance at $72 \%$ and the LI having the highest at 94\% (Table 2. 5). Sugar maple abundance increased in all three single-tree selection treatments from 1956 to 2018, as well as in the control, DL30, and DL56, with the STS21 and DL56 having the greatest gains (+13\%) in sugar maple relative abundance. Notably the DL41 had the greatest decrease in relative abundance of sugar maple (-7\%) from 1956 to 2018. In 2018, the control had the highest relative abundance of sugar maple at $97 \%$. Yellow birch relative abundance decreased with time in all treatments except for the STS11.

Table 2. 5 Initial 1956 pre-treatment relative species abundance (\%) and total change to pre-harvest 2018, for trees $>12.6 \mathrm{~cm}$ dbh, in 1956 and 2018 .

\begin{tabular}{|c|c|c|c|c|c|c|c|c|}
\hline \multirow[t]{2}{*}{ Treatment } & \multicolumn{2}{|c|}{$\begin{array}{c}\text { Acer } \\
\text { saccharum }\end{array}$} & \multicolumn{2}{|c|}{$\begin{array}{c}\text { Betula } \\
\text { alleghaniensis }\end{array}$} & \multicolumn{2}{|c|}{$\begin{array}{c}\text { Ulmus } \\
\text { americana }\end{array}$} & \multicolumn{2}{|c|}{ Other $^{\mathrm{a}}$} \\
\hline & Initial & $\Delta$ & Initial & $\Delta$ & Initial & $\Delta$ & Initial & $\Delta$ \\
\hline DL56 & 76 & +13 & 6 & -2 & 6 & -5 & 11 & -6 \\
\hline DL41 & 86 & -7 & 7 & -6 & 6 & +1 & 1 & +12 \\
\hline DL30 & 79 & +1 & 6 & -6 & 6 & -3 & 8 & +9 \\
\hline DL13 & 88 & -4 & 3 & -3 & 5 & +2 & 4 & +5 \\
\hline STS21 & 72 & +13 & 12 & -9 & 12 & -11 & 4 & +7 \\
\hline STS16 & 80 & +4 & 14 & -11 & 3 & 0 & 3 & +7 \\
\hline STS11 & 76 & +10 & 8 & 0 & 8 & -2 & 8 & -8 \\
\hline LI & 94 & -4 & 0 & 0 & 6 & +1 & 0 & +3 \\
\hline Control & 90 & +7 & 5 & -4 & 1 & -1 & 4 & -2 \\
\hline
\end{tabular}

\footnotetext{
a Other may include one or more of: Betula papyifera, Picea glauca, Prunus serotina, Ostrya virginiana, Tilia americana, or Tsuga canadensis
} 


\subsection{Discussion}

The continuation of the cutting methods study through 2018 extends the results reported at year 22 (by Reed et al. 1986) and year 32 (by Erickson et al. 1990) to a total of 62 years. A key finding after the additional 30 years is the consistent superiority of the DL41 treatment over all others on both financial, harvested grade, and volume production criteria. This is a surprising result, given diameter-limit cutting is routinely critiqued as either inferior to selection, because of the lack of tending in residual size classes to improve tree quality (e.g., Niese et al. 1995, Kenefic et al. 2005, Kenefic and Nyland 2005, Fajvan 2006), or ultimately dysgenic, by the repeated removal of trees of superior vigor that grow beyond the diameter limit and are removed in future cycles (e.g., Buongiorno et al. 2000, Erickson et al. 1990, Howe 1989, Nyland 1988, O'Hara 2002). Indeed, in the cutting methods study no tending was performed in the residual trees below the diameter limit across the entire 62-year duration, and over the past 30 years there has been no improvement in residual tree grade. Paradoxically, however, the DL41 has consistently and reliably produced the highest average annual yield of any treatment, greatest grade 1 harvested volumes, and a superior distribution of harvested tree grade that is exceeded only recently by the LI and STS21 (Table 2. 3).

The first 32 years of the study demonstrated clear improvements in residual tree grade under all of the treatments, including in the reserve. Average standing tree grade can increase in time because inferior trees are targeted for removal, but also trees can simply grow large enough to cross size thresholds that delimit higher grades. By examining grade of only trees $\geq 46 \mathrm{~cm}$ dbh it appears to be clear that grade improvements have occurred through management. The key unanswered question posed by Reed et al. (1986) and Erickson et al. (1990) was whether, in time, one or more of the STS treatments could "catch up" to the DL41 because of an increasing grade profile. The results here clearly demonstrate a steady increase in standing tree grade in the STS and in particular in the LI since 1988, along with an associated increase in harvested tree grade. This makes sense, as eventually if inferior trees are removed only the superior trees remain to be harvested. However, these 
increases have not translated into increases in revenue that, even without discounting, have proved superior to the DL41 (Figure 2. 4).

The failure of the STS or LI treatments to financially surpass the $41 \mathrm{DL}$ is, in retrospect, not particularly surprising. Financial return depends on both grade profile of harvested trees and periodic yield. Given the threshold diameter for a grade 1 sawlog is 41 cm (USDA Forest Service 2008), in the DL41 soon after trees cross the threshold they are removed, leaving behind only smaller grade 2 and 3 trees that may increase in grade through the next cycle as they grow beyond size thresholds. Because STS treatments will retain some trees that already meet the size criteria for grade 1, much of the increase in value in those trees can come only from volume growth; however, growth is penalized by discounting, and these treatments in general have lower periodic yield than the DL41. Moreover, by maintaining some stocking in trees as large as $61 \mathrm{~cm}$, any grade 2 trees that are approaching the $41 \mathrm{~cm}$ threshold are deprived of growing space leading to slower growth. The same logic can explain the inferiority of the DL56 and DL30 to the DL41. With a large threshold diameter, the DL56 carries many grade 1 trees to the next cycle and overall high residual basal area seems equated with low periodic yield. In contrast, while the DL30 has had high periodic yield over the life of the study, the low threshold diameter ensures that trees rarely, if ever, grow large enough to meet the much more valuable grade 1 specification before they are harvested in the next entry.

The DL41 is effectively a "sweet spot", at least in this maple-dominated forest type, re-entry cycle, and level of site productivity, holding the greatest number of smaller sawtimber-sized grade 2 trees which are poised to increase significantly in grade and value between cycles (Godman and Mendel 1978; Power and Havreljuk 2018; Reed and Mroz 1997; Webster et al. 2009). Because the DL30 also holds a large proportion of grade 2 trees post-harvest, it too has the potential for significant grade improvement. A lower diameter threshold for grade 1, a longer re-entry cycle, or higher site productivity would likely improve the financial performance of the DL30. The STS11 also holds a significant proportion of grade 2 trees (Figure 2. 1) and, combined with comparatively high periodic growth, has shown strong financial performance, especially in the last 30 years. Ultimately, 
however, while the STS11 is perhaps the closest of the STS treatments to the "sweet spot" occupied by the DL41, the retention of some large trees beyond the grade 1 diameter threshold means some opportunity cost will always occur. This cost is only amplified by the potential loss of high-value residual trees due to destructive weather or degrade due to damage or decay. For example, in the Lake States there is an issue with increasing dark heart as trees age, and this defect degrades logs that would otherwise meet grade one or higher standards (Erickson et al. 1992). To minimize this opportunity cost, Reed and Mroz (1997) suggested favoring removal of larger grade 1 and 3 trees if single-tree selection is the chosen method. This captures value in grade 1 trees before any future degrade and concentrates growth on grade 2 trees which still contain some quality sawlogs.

While the top-performing treatment by MFV has been consistently the DL41, significant shifts in ranking have occurred since 1988. For example, Erickson et al. (1990) suggested that the light improvement receive special attention, because of significant improvement in residual tree grade over the first 32 years and excellent performance based on MFV. However, while the LI was ranked $2^{\text {nd }}$ in 1988 , it has since been surpassed by the STS11 and STS16, which are now ranked $2^{\text {nd }}$ and $3^{\text {rd }}$, respectively (Table 2. 4 Comparison of MFV and periodic return from first two decades after sustainable stand structure was assumed at the Ford Forest study, and from the past three decades, with sawlog products valued at price in 2018 dollars. Discount rates of 2\% and 4\% are shown.). By 2018 the LI easily has the best standing tree and harvested log grade profile, but middling and declining periodic yield does not allow the superior grade profile to be translated into outstanding financial return. In contrast, while the improvement in harvested grade was more modest in the STS11 and STS16, periodic yield has increased substantially. Since 1988, the already poorly ranked DL30 and DL13 treatments have further decreased in ranking, suggesting that extremely low residual basal area can be problematic. The DL13 treatment in particular has no redeeming qualities; it has extremely low MFV, poor structural diversity, and is easily outperformed in average sawtimber volumes harvested per year over the last 40 years by every other treatment. Harsh diameter-limit cuts like the DL13 and DL30 also present 
a theorized greater potential to accumulate dysgenic effects through time (Buongiorno et al. 2000).

Divergence of structure and density between the selection and diameter-limit treatments was present by post-harvest 1988, with the diameter-limit treatments retaining more trees in the pole and smaller sawtimber size classes (Figure 2. 5) and increasing in TPH where selection treatment stem numbers have consistently decreased (Figure 2. 6). However, structure since then has appeared to stabilize, with the same differences present in 2018. Consistency in structure and density lends greater weight to the financial analysis results due to the implication of sustained future yield; density is particularly important since it does affect quality in hardwoods, as higher density causes better form in survivor trees (Godman and Brooks 1971; Sonderman 1985). The greater numbers of stems present in the DL41 over the past 30 years bode well for the sustainability of its current quality and volume yield into the future.

Other investigations have found that medium-intensity diameter-limit cuttings can produce sustained volume yield. Smith and Miller (1987) reported that a $40 \mathrm{~cm}$ diameterlimit cut had the greatest periodic annual board foot production when compared to two selection treatments and a clearcut, as well as the greatest compounded periodic harvest value. Results from Buongiorno et al. (2000) also suggest that sustainable management of Lake States northern hardwoods with diameter-limit cutting is possible; a $38 \mathrm{~cm}$ cut performed similarly to a heavy selection cut, with high overstory diversity as well as high present value and periodic harvest values. Interestingly both Smith and Miller (1987) and Buongiorno et al. (2000) recommend that a medium-intensity diameter-limit cut could be improved by removing poorly performing understory trees in order to increase future quality. This would effectively result in a diameter-limit treatment with stand improvement and would likely increase value and performance of treatments like the DL41 even more, a conclusion that can be tested in future studies, or through actual implementation by managers in the field. 
As currently recommended in the Lake States, single-tree selection retains residual stocking levels of 16 to $21 \mathrm{~m}^{2} \mathrm{ha}^{-1}$ and is concerned with obtaining a specific residual reverse-J diameter distribution (Arbogast 1957; Eyre and Zillgitt 1953; Gilbert and Jensen 1958; Nyland 1998; Tubbs 1977a), a structure commonly found in balanced, uneven-aged stands and widely accepted as a representation of such (Leak et al. 1987; Leak 1996; Nyland 2016). However, long-term application has not only been associated with a lack of regeneration, but also with a reduction in overstory species and structural diversity (Angers et al. 2005; Gronewold et al. 2010; Neuendorff 2007). Silvicultural methods that vary harvest intensity and stand structure can help mitigate or avoid the decline in overstory diversity that accompanies traditional single-tree selection (Hanson and Lorimer 2007), and in some studies partial cutting methods including diameter-limit cuts and selection to lower residual basal areas have been associated with higher overstory species diversity (Buongiorno et al. 2000; Niese and Strong 1992). Indeed, in this study the DL41 had the greatest decrease in sugar maple relative abundance since 1956, while abundance increased in all three selection treatments. Selection treatments that cut to lower residual basal areas than traditionally recommended have also been shown to help accommodate regeneration of less shade tolerant species (Bodine 2000; Leak et al. 1987; Tubbs 1977b), and the STS11 was the only treatment to not decrease in relative abundance of the intermediately tolerant Betula alleghaniensis Britt. (Table 2. 5). Heavier cuttings and disturbance in northern hardwoods long-term management have been found to result in a rotated sigmoid diameter distribution that could be accompanied by an increase in softwoods and species diversity (Leak 1996). Higher intensity partial cutting also helps prevent the homogenization of understory stand structure common with single-tree selection (Angers et al. 2005), and decayed trees are common in diameter-limit cut stands, both factors important to wildlife habitat (Kenefic and Nyland 2005). Lower residual basal areas such as those found in the DL41, DL30, and STS11 also result in higher light availability, a factor associated with greater regeneration densities in Great Lakes northern hardwoods (Matonis et al. 2011). This is shown in how the DL41 and DL30 are doing a better job than the selection treatments of continually recruiting more trees into the smaller size classes (Figure 2. 5), contributing to structural diversity and implying greater levels of regeneration. Diameter- 
limit cuts have also been found to have a higher genetic diversity while containing rare alleles that may in the future be adaptively beneficial, which is particularly relevant in the context of climate change (Hawley et al. 2005).

Overall, the DL41 and STS11 treatments perform well financially while also providing motivations apart from financial gain to consider alternatives to traditional single-tree selection in northern hardwoods, due to their favorable performance under ecological metrics such as species and structural diversity. This is especially important given concerns about the lack of regeneration under traditional uneven-aged single-tree selection silviculture (Bassil et al. 2019; Hupperts et al. 2019; Previant 2015). Due in part to those concerns, evaluating alternatives has become a point of interest for forest managers, with recent studies calling for alternatives to selection silviculture as it is currently practiced in northern hardwoods (Henry et al. 2021; Hupperts et al. 2019; Matonis et al. 2011) while also finding it is frequently applied in a manner inconsistent with accepted standards (Pond et al. 2014). Recognizing that alternatives to traditional single tree-selection, such as the DL41 and STS11, have the potential to address concerns about increased species diversity, structural diversity, and regeneration in northern hardwoods is increasingly significant in the face of climate change and prospective future changes in disturbance regimes (Campione et al. 2012; D’Amato et al. 2011; Gustafson et al. 2020). 


\section{Six Decades of Financial Returns and Stand Dynamics in the Argonne Experimental Forest Cutting Methods Study}

\subsection{Introduction}

As historically applied in northern hardwoods, single-tree selection reduces basal area to around 18-21 square meters per hectare with an emphasis on maintaining a specific diameter distribution (Arbogast 1957; Eyre and Zillgitt 1953; Gilbert and Jensen 1958; Nyland 1998; Tubbs 1977). Current selection management recommendations in Lake States hardwoods do not vary much from this (Pond et al. 2014). However, there have recently been increasing concerns about lack of regeneration, species diversity, recruitment, and the overall sustainability of the selection system in northern hardwoods (Campione et al. 2012; Hupperts et al. 2019; Previant 2015). Species and structural diversity in particular are of growing importance in our forests as climate change and shifting disturbance regimes increasingly become potential management concerns (D'Amato et al. 2011). As a result, alternatives to single-tree selection to the traditionally higher residual basal areas are being considered, and many recent publications have called for alternatives to selection practices as they are currently prescribed in northern hardwoods (Campione et al. 2012; Henry et al. 2021; Matonsis et al. 2011; Danyagari et al. 2018). Management methods such as group selection, diameter-limit treatments, and selection to lower residual basal areas are some such alternatives all having a history of use in the Lake States.

Most single-tree selection as prescribed in Lake States hardwoods follows the Arbogast (1957) guide that calls for reduction in overstory basal area to around 19.5 square meters per ha while retaining a specific reverse-J diameter distribution. Such management is known to increase quality of hardwoods and produce sustained yield (Eyre and Zillgitt 1953; Nyland 2016). However other partial cutting management methods can produce similarly desirable results. Medium-intensity diameter-limit treatments have been seen to produce of high-quality sawtimber and sustained yield while simultaneously outperforming selection treatments (Smith and Miller 1978; Buongiorno 2000; Erickson et 
al. 1990). Crop-tree treatment is a version of a pre-commercial thinning used in northern hardwoods that focuses on improving quality and growth rates of individual trees (Leak 2014), and residuals in thinned northern hardwoods stands grow faster than those in an unthinned control (Leak 2007). Thinning is successful when the value increase of residuals is outweighed by the volume loss (Zeide 2001). Single-tree selection systems that reduce basal area further than Arbogast (1957) recommends have benefits such as higher overstory species diversity and better financial performance (Erickson et al. 1990; Niese and Strong 1992). Long-term comparison and analysis of these various partial cutting treatments is important to help determine if they present viable silvicultural alternatives to traditional selection practices in Lake States northern hardwood forests.

However, changes in management are often not enacted without sufficient financial incentive. The lifespan and comparably slower growth of northern hardwoods forests ensure that financial analyses incorporating long-term results are particularly important. Tree quality in particular should be considered when evaluating long-term financial value of stands, as financial value in northern hardwoods sawtimber is strongly influenced by quality (Godman and Mendel 1978). Due to their influence on financial value, the metrics used to estimate quality in northern hardwood logs and standing timber, such as diameter, merchantable height, and percent cull, all become important indicators of the value of the stand. Management guides are often chosen with the objective of increasing sawlog volume production (Nyland 2016), however established economic theory recognizes that increasing quality and consequently value of saleable removals will increase financial return, particularly when stand value and volume are not directly correlated (Zobrist 2014; Lussier 2009). Single-tree selection emphasizes the improvement of the quality of the residuals (Leak 2014; Kenefic et al. 2005), but this improvement only translates to an increase in actual financial returns if those improved trees are removed at a later date. Thus silvicultural treatments that periodically remove all highest quality and large timber, while leaving pole and mid-sized intermediate quality growing stock maximize value (Lussier 2009; Reed and Mroz 1997). 
Past financial analyses of alternative management methods in Lake States northern hardwoods have found that medium-intensity diameter-limit treatments, as well as selection systems focusing on quality, outperform selection treatments to residual basal areas of 18-21 m²ha-1 (Reed et al. 1986; Erickson et al. 1990; Buongiorno et al. 2000). Long-term studies in northern hardwoods have also previously shown that selection treatments to residual basal areas around 16-17 $\mathrm{m}^{2} \mathrm{ha}^{-1}$ increase hardwood tree quality and value more than comparable treatments to $21 \mathrm{~m}^{2} \mathrm{ha}^{-1}$ (Bodine 2000; Niese et al. 1995; Strong et al. 1995), and that lower residual basal area in selection treatments can result in greater post-harvest diameter growth, periodic growth, and lower mortality (Forget et al. 2007; Schuler and McGill 2007). The long-term study at the Argonne Experimental Forest (EF) in northern Wisconsin provides an exceptional opportunity to compare selection treatments to various residual basal areas and evaluate their effect on growth, quality, and value in an even-aged forest managed with traditionally uneven-aged management methods. Single-tree selection, group selection, and diameter-limit treatments across three replications have all been maintained for almost 70 years, and these prescriptions have accumulated different results through the lenses of financial analysis, growth, yield, and quality metrics.

Niese et al. (1995) and Strong et al. (1995) wondered which of the treatments maintained in this study allow for compatibility between high quality and value northern hardwoods management and management for ecosystem health; in the context of these previous studies it was hypothesized that if quality improvement and higher volume yield continued in selection treatments to lower residual basal areas, these would outperform other partial cutting treatments after an additional 25 years of management. To measure treatment performance, a specific objective was to evaluate the financial success of each treatment based on solely harvested lumber volumes and values by completing a new analysis following Rideout (1985) that includes financial analysis methodology tailored to partial cutting methods, in contrast to the cash-flow analysis incorporating residual volume values from Niese et al. (1995). A final objective was to evaluate the sustainability of the treatments both financially and ecologically. This was done through the analysis of growth, mortality, and yield, as well as composition and structure due to their importance in 
management prescriptions and field guides. Strong et al. (1995) in particular emphasize the importance of recruitment and continuous movement from one size class to another, and so special attention was paid in this evaluation to ingrowth, mortality, and structure through time.

\subsection{Methods}

\subsubsection{Study site}

The Argonne EF consists mostly of second-growth, even-aged forest, which at study establishment in 1951 were primarily 45 years old, although there were some few residual poor quality trees older than the main stand (Stoeckler 1955). The experimental forest is located in Forest County, Wisconsin, with the study site being considered good for northern hardwoods and having a site index of 19-21 m base age 50 (Strong et al. 1995). The Acer/Osmorhiza-Caulophyllum habitat type and Argonne-Sarwet sandy loams with 1 to 6 percent slopes occupy most of the site (Kotar et al. 2002; USDA Natural Resources Cons. Serv.). Pre-treatment at study commencement in 1951 density averaged just over 21 $\mathrm{m}^{2} \mathrm{ha}^{-1}$ basal area in trees $>11.4 \mathrm{~cm}$ diameter $(\mathrm{dbh})$, with sugar maple (Acer saccharum Marsh.) accounting for 57 percent of that basal area, basswood (Tilia americana L.) 10 percent, hemlock (Tsuga canadensis L.) 9 percent, yellow birch (Betula alleghaniensis Britt.) 8 percent, white ash (Fraxinus americana L.) 6 percent, plus the occasional red maple (Acer rubrum L.), American elm (Ulmus americana L.), paper birch (Betula papyifera Marsh.), black ash (Fraxinus nigra Marsh.), black cherry (Prunus serotina Ehrh.), aspen (Populus spp.), and ironwood (Ostrya virginiana Mill.) individuals making up the remainder (Erdmann and Oberg 1973).

\subsubsection{Long-term study design}

Nine different treatments, including a control, are grouped together in a randomized block design with three blocks each comprising 16.2-ha. Blocks 1, 2, and 3 are located at approximately $45^{\circ} 44^{\prime} 37.6836^{\prime \prime} \mathrm{N}, 88^{\circ} 59^{\prime} 19.4064 " \mathrm{~W}, 45^{\circ} 44^{\prime} 54.96^{\prime \prime} \mathrm{N}, 88^{\circ} 58^{\prime} 7.464 "$ $\mathrm{W}$, and $45^{\circ} 45^{\prime} 36.1908^{\prime \prime} \mathrm{N}, 88^{\circ} 57^{\prime} 59.7888^{\prime \prime} \mathrm{W}$, respectively. Three of the treatments (strip cutting, clearcut, and shelterwood) were applied historically but not maintained for the entirety of the study. The remaining six treatments have been regularly applied and 
maintained for the past 68 years. These are single-tree selection to a residual basal area of 21, 17, and $14 \mathrm{~m}^{2} \mathrm{ha}^{-1}$, an 18 centimeter diameter-limit cut, a crop tree treatment, and a control. Each individual treatment compartment for these six treatments is 1.01 ha. Within each compartment are five 0.04-ha circular permanent measurement plots with trees individually numbered. The original purpose of the study was to observe and collect data on changes in growth, mortality, stand structure, and yield between the different treatments over time, as well as to determine the economic feasibility of the various management methods (Stoeckler 1955; Niese and Strong 1992).

This analysis evaluates the previously mentioned six treatments that have been maintained throughout the study. The three single-tree selection treatments were applied on a 10-year cycle with entries during the winters of 1952, 1962, 1972, 1982, 1992, 2002, and 2012. The $14 \mathrm{~m}^{2} \mathrm{ha}^{-1}$ single-tree selection (STS14) treatment reduces trees $>11.4 \mathrm{~cm}$ $\mathrm{dbh}$ to a residual basal area of $14 \mathrm{~m}^{2} \mathrm{ha}^{-1}$ with a goal of a size class distribution with a $q$ value of 1.3. The $17 \mathrm{~m}^{2} \mathrm{ha}^{-1}$ single-tree selection (STS17) and $21 \mathrm{~m}^{2} \mathrm{ha}^{-1}$ single-tree selection (STS21) treatments similarly reduce trees $>11.4 \mathrm{~cm}$ dbh to residual basal areas

of 17 and $21 \mathrm{~m}^{2} \mathrm{ha}^{-1}$, respectively, with the same desired diameter distribution. Trees were selected for harvest to remove high risk, cull, and trees in overstocked size classes, and to release crop trees.

In the crop tree release treatment, 25-50 selected trees were released to grow by thinning the crown to a residual basal area of $14 \mathrm{~m}^{2} \mathrm{ha}^{-1}$ in $1952,17 \mathrm{~m}^{2} \mathrm{ha}^{-1}$ in 1972,17 $\mathrm{m}^{2} \mathrm{ha}^{-1}$ in $1982,19 \mathrm{~m}^{2} \mathrm{ha}^{-1}$ in 2002, and $21 \mathrm{~m}^{2} \mathrm{ha}^{-1}$ in 2012, with small trees left near the crop tree as trainers (Strong et al. 1995). The $18 \mathrm{~cm}$ DL diameter-limit (DL18) treatment has only been cut twice over the length of the study; in 1952 and 1992 all trees $20 \mathrm{~cm}$ and larger at a 30.5 -cm stump height, equivalent to about $18 \mathrm{~cm} \mathrm{dbh}$, were cut.

\subsubsection{Measurements}

Beginning in 1952, individual trees were numbered and tracked through time within each 0.04-ha measurement plot with dbh and species recorded at a maximum of 5-year intervals. Butt-log grade was recorded pre-harvest as an estimate of standing tree quality for all sawtimber-sized trees in 1972, 1982, 1992, 2002, and 2016, and for harvested trees 
only in 1952 and 1962, using the U.S. Forest Service tree grading system (Hanks 1976). Cull percent and merchantable height as number of $4.88 \mathrm{~m}$ (16-ft) logs were recorded in these same years. Total sawtimber removals and residual standing timber volumes were estimated using Gevorkiantz and Olsen (1955) volume tables (Intl. 1/4" rule) for Lake States hardwoods. Volume conversion to cubic meters follows Winn et al. (2020).

\subsubsection{Financial analysis}

A financial analysis was performed in the style of Rideout (1985), similar to the ones presented by Reed et al. (1986) and Erickson et al . (1990) for the Bourdo study. Three different measures of financial performance were calculated: managed forest value (MFV), present worth (PW) in 1952, and total value of all harvests discounted to 1952. Values presented in dollars per hectare are not an average per block but instead an actual value for entire study area. MFV and PW were used as financial criteria to evaluate treatments. No cost factors were introduced into the analysis due to the intent to compare relative, not absolute, measures of financial returns between treatments. MFV is the discounted value of the sum of an infinite series of harvests, and is intended to represent the long-term applicability of a silvicultural system, while PW is the sum of all revenues plus MFV, both discounted to 1952. MFV, as defined by Rideout (1985), requires sustainable stand structure to have been reached. Selection system silviculture treatments can require two cuttings to properly implement and reach 'sustainable stand structure' (Nyland 1998; Reed et al. 1986; Erickson et al. 1990), so for this analysis sustainable stand structure was assumed to have been reached in 1972 after two initial harvests. Financial performance was compared between each treatment and the control using discount rates of 2, 4, 6, and $8 \%$.

This financial analysis evaluated the lumber value return of sawlogs. Potential factory grade lumber yield estimates for harvested trees were found using equations from Hanks (1976) and incorporated differences in quality into the financial analysis. Trees were also graded following methodology in Hanks (1976), so the equations for factory grade lumber yields could be accurately applied. Lumber prices were acquired from Hardwood Market Report (D. Caldwell, personal communication, October 5, 2020) with supplemental 
data from Luppold et al. (2001). Accurate regional historic pricing from each year of harvest was used, adjusted to a common 2018 basis using the producer price index for lumber and wood products (U.S. Bureau of Labor Statistics).

\subsubsection{Data analysis}

An analysis of variance (ANOVA) was completed to evaluate differences in treatment means for variation in grade, merchantable height, dbh, yield, ingrowth, and mortality using $\mathrm{R}$ version 4.0.2 (R Core Team 2020). The model used was for a randomized complete block design with subsampling (Kuehl 2000). When the ANOVA indicated statistically significant $(p<0.05)$ differences between treatments, post-hoc comparisons using the Tukey HSD test were made with the 'emmeans' package v1.4.7 (Lenth 2020). For species diversity, Shannon's diversity index ( $\left.\mathrm{H}^{\prime}\right)$ was calculated in R for the overstory (trees $>11.4 \mathrm{~cm} \mathrm{dbh}$ ) pre-treatment in 1951 and pre-harvest in 2011 using the 'vegan' package v2.5-6 (Oksanen 2020). 


\subsection{Results}

\subsubsection{Growth and yield}

Average diameter growth for survivor trees through the entire study period was greatest under the STS14 treatment at $29 \mathrm{~cm}$, or $0.45 \mathrm{~cm}$ per year, followed by the STS17 at $0.40 \mathrm{~cm}$ per year (Table 3.1). The STS21 treatment had lowest average diameter growth after the control. The STS14 and STS17 treatments also had the greatest average merchantable heights in 2016. From 1972 to 2016, average merchantable height increased in all treatments except the DL18 and the control (Table 3.2).

Table 3.1 Argonne EF average dbh $(\mathrm{cm})$ in 1951 (pre-treatment), 1952 (post-treatment), 2016 ( 4 years post-treatment), and average increase in diameter of individual trees $\geq 11.4$ $\mathrm{cm}$ dbh from 1952 - 2016. In the DL18 treatment there were no survivor trees for that time period. Standard error in parentheses, $n=15$. Means in a column followed by the same letter are not significantly different, $p<0.05$.

\begin{tabular}{ccccc}
\hline Treatment & 1951 & 1952 & 2016 & $\Delta$ dbh \\
\hline STS14 & $19.87(.84) a$ & $19.02(.93) a b$ & $24.64(.99) b c$ & $28.97(1.1) a$ \\
STS17 & $21.49(.50) a$ & $20.94(.46) a$ & $27.69(1.2) b c$ & $25.92(.72) a$ \\
Crop tree & $19.74(.65) a$ & $18.73(.64) a b$ & $28.96(1.1) b$ & $22.98(1.2) a b$ \\
STS21 & $21.34(.72) a$ & $20.86(.66) a$ & $29.72(1.5) a b$ & $22.94(.99) a b$ \\
Control & $20.33(.90) a$ & $20.33(.90) a$ & $35.81(1.5) a$ & $17.56(1.2) b$ \\
DL18 & $19.77(.81) a$ & $14.82(.37) b$ & $22.61(1.0) c$ & --- \\
\hline
\end{tabular}

Table 3.2 For trees $>24 \mathrm{~cm}$ dbh at the Argonne EF, average merchantable height by number of 4.88-meter logs in 1972 and 2016. Standard error in parentheses, $n=15$. Means in a column followed by the same letter are not significantly different, $\mathrm{p}<0.05$.

\begin{tabular}{ccc}
\hline Treatment & 1972 & 2016 \\
\hline STS14 & $1.52(.082) a$ & $1.76(.096) a$ \\
STS17 & $1.64(.050) a$ & $1.73(.094) a$ \\
Crop tree & $1.42(.063) a$ & $1.61(.073) a$ \\
STS21 & $1.57(.085) a$ & $1.60(.114) a$ \\
Control & $1.47(.044) a$ & $1.22(.059) a b$ \\
DL18 & $1.29(.048) a$ & $0.72(.085) b$ \\
\hline
\end{tabular}


Average annual ingrowth into the smallest measured diameter class has been significantly greatest in the DL18 for the entire study period (Figure 3.1). The highest levels of ingrowth for the DL18 were directly following harvest in the 1960s, and 2000s. The control had significantly lower levels of annual ingrowth than all other treatments. Mortality was lowest in the STS14 at $0.028 \mathrm{~m}^{2} \mathrm{ha}^{-1} \mathrm{yr}^{-1}$. All three selection treatments minimized mortality, but were only significantly different than the control treatment which had easily the highest mortality rate at $0.265 \mathrm{~m}^{2} \mathrm{ha}^{-1} \mathrm{yr}^{-1}$ (Figure 3.1).
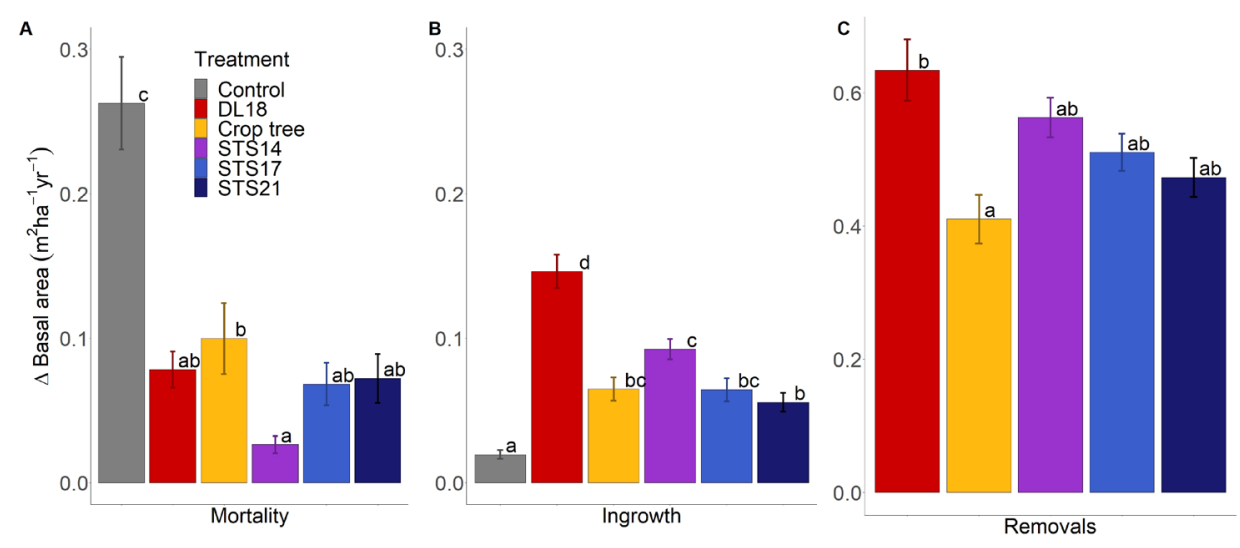

Figure 3.1 Average annual ingrowth (into the smallest measured size class), mortality $\left(\mathrm{m}^{2} \mathrm{ha}^{-1} \mathrm{yr}^{-1}\right)$, and removals $\left(\mathrm{m}^{2} \mathrm{ha}^{-1} \mathrm{yr}^{-1}\right)$, for the entire study period at the Argonne EF. Within each graph (A, B, C) bars with the same letter are not significantly different, $p<$ $0.05, n=15$.

Basal area (BA) has exhibited a consistent, gentle decline through time for the selection and crop tree treatments through time, with similar but slightly lower BAs in 2016 than in 1951 (Figure 3.2A). The second DL18 harvest reduced both BA and trees per ha (TPH) to much lower levels in 1992 than at any point previously, and the treatment has still not recovered to previous density levels. All treatments including the control have markedly lower TPH now than at the commencement of the study; there was a steady decline in TPH from 1951 on, until the late 1990s and early 2000s when there began an increase in TPH in all selection treatments and the DL18 (Figure 3.2B). 

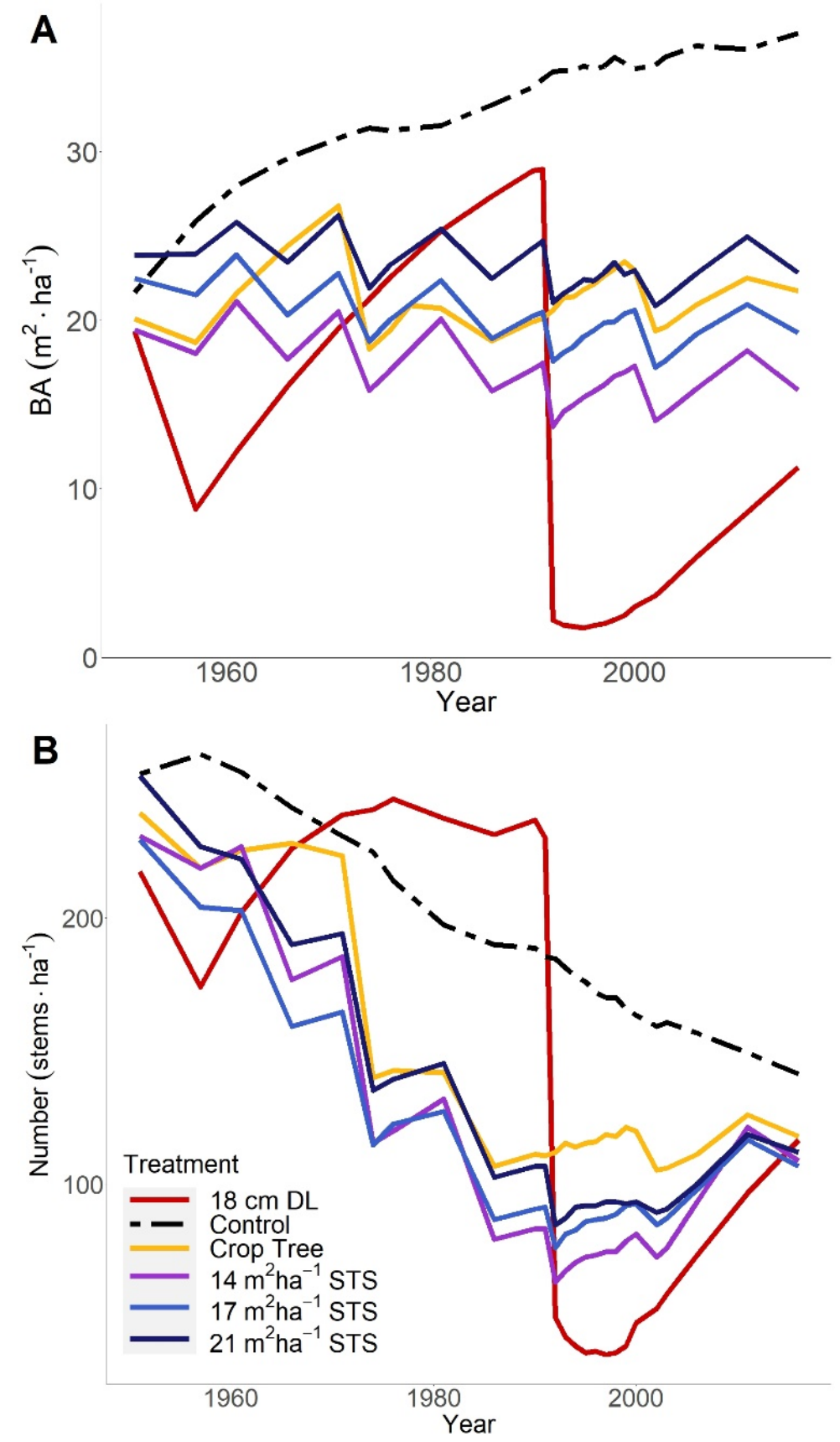

Figure 3.2 Stand density through time for trees $\geq 11.4 \mathrm{~cm}$ dbh at the Argonne EF. A) Basal area and B) trees per hectare from $1951-2016$. 
Estimated dry sawn lumber volume was greatest for the STS14 and STS17 (Table 3.3). The two DL18 harvest entries produced much greater volumes than any other treatment in their specific harvest entry years, but due to the 40 -year rotation time, the selection treatments outpace the DL treatment in total annual yield rates. Residual volume since 1972 has seen lumber volumes consistently increasing in the crop tree and control treatments (Table 3.4). Residual volumes in the selection treatments have persisted as expected, with the STS14, STS17, and STS21 treatments each retaining more volume than the previous, respectively (Table 3.4, Figure 3.3). Net volumes in the selection treatments increased from 1972 to 1982 , have since fluctuated around similar levels, within $11 \mathrm{~m}^{3} \mathrm{ha}^{-}$ ${ }^{1}$ of the net volumes reached in 1982 .

Table 3.3 Average annual dry factory grade sawn lumber yield since 1972 (estimated following Hanks (1976), $\mathrm{m}^{3} \mathrm{ha}^{-1} \mathrm{yr}$ ) by grade at the Argonne EF. Grade $1 \mathrm{C}+$ includes selects and better. Within each column values with the same letter are not significantly different, $p<0.05, n=15$. Conversion to cubic meters following Winn et al. (2020).

\begin{tabular}{cccc}
\hline Treatment & $1 \mathrm{C}+$ & $2 \mathrm{~A}, 2 \mathrm{~B}, 2 \mathrm{C}$ & $3 \mathrm{~A}, 3 \mathrm{~B}$ \\
\hline STS14 & $.710(.099) a$ & $.482(.054) a$ & $.585(.076) a$ \\
STS17 & $.684(.090) a$ & $.473(.062) a$ & $.391(.059) b$ \\
STS21 & $.549(.097) a$ & $.356(.062) a$ & $.293(.043) b$ \\
DL18 & $.366(.063) a$ & $.396(.057) a$ & $.579(.058) a$ \\
Crop tree & $.328(.065) a$ & $.315(.053) a$ & $.287(.042) b$ \\
\hline
\end{tabular}

Table 3.4 Argonne EF residual sawtimber volumes ( $\mathrm{m}^{3} \mathrm{ha}^{-1}$, Intl. 1/4" rule) estimated by number of logs following Gevorkiantz and Olsen (1955) for trees $>24 \mathrm{~cm}$ dbh. In 2002 merchantable height was not measured for the DL18 and crop tree treatments, so volume could not be estimated using Gevorkiantz and Olsen (1955). Conversion to cubic meters following Winn et al. (2020).

\begin{tabular}{ccccccccccc}
\hline \multirow{2}{*}{ Treatment } & \multicolumn{2}{c}{1972} & \multicolumn{2}{c}{1982} & \multicolumn{2}{c}{1992} & \multicolumn{2}{c}{2002} & \multicolumn{2}{c}{2012} \\
\cline { 2 - 10 } & Gross & Net & Gross & Net & Gross & Net & Gross & Net & Gross & Net \\
\hline DL18 & 21.0 & 21.0 & 43.5 & 43.3 & 0.0 & 0.0 & NA & NA & 16.5 & 15.2 \\
Control & 69.7 & 68.9 & 89.3 & 87.3 & 97.7 & 94.7 & 118.6 & 97.5 & 137.1 & 123.3 \\
Crop tree & 47.3 & 47.0 & 66.4 & 65.9 & 82.3 & 81.4 & NA & NA & 97.7 & 88.1 \\
STS14 & 53.3 & 52.7 & 67.7 & 66.6 & 72.9 & 71.0 & 75.1 & 67.2 & 72.7 & 69.3 \\
STS17 & 64.4 & 63.6 & 86.0 & 84.5 & 80.6 & 78.1 & 84.1 & 72.2 & 89.0 & 83.5 \\
STS21 & 73.5 & 72.3 & 91.3 & 88.8 & 101.7 & 97.7 & 102.5 & 90.5 & 104.7 & 98.3 \\
\hline
\end{tabular}




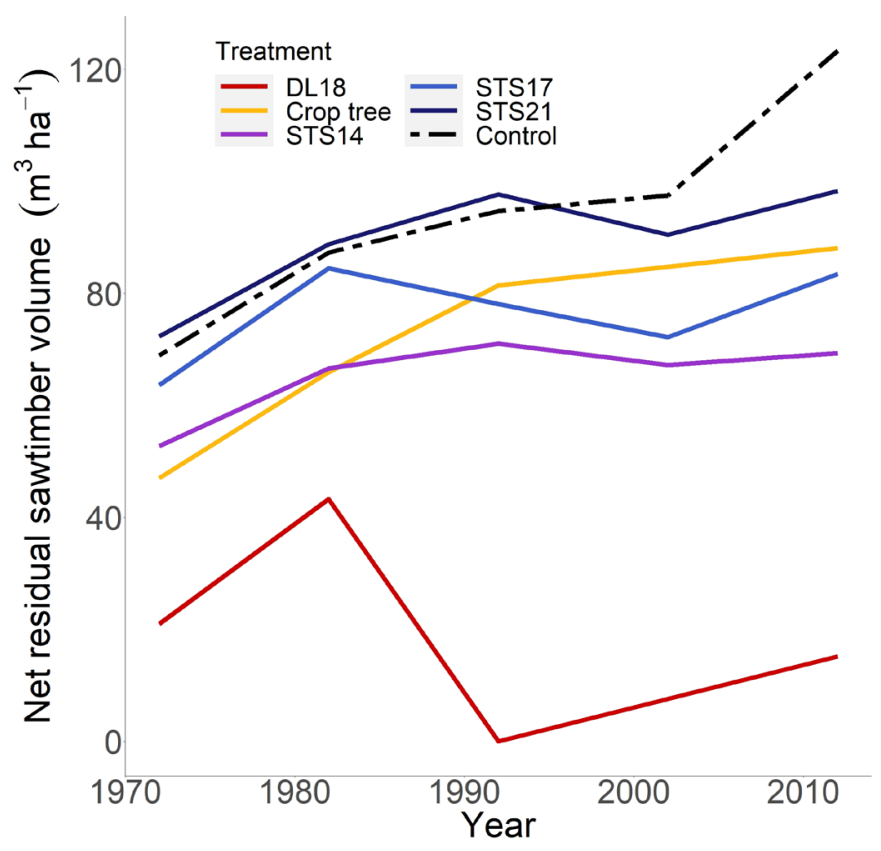

Figure 3.3 Argonne EF net residual sawtimber volume $\left(\mathrm{m}^{3} \mathrm{ha}^{-1}\right.$, Intl. 1/4" rule) estimated by number of logs following Gevorkiantz and Olsen (1955) for trees $>24 \mathrm{~cm} \mathrm{dbh}$. Conversion to cubic meters following Winn et al. (2020).

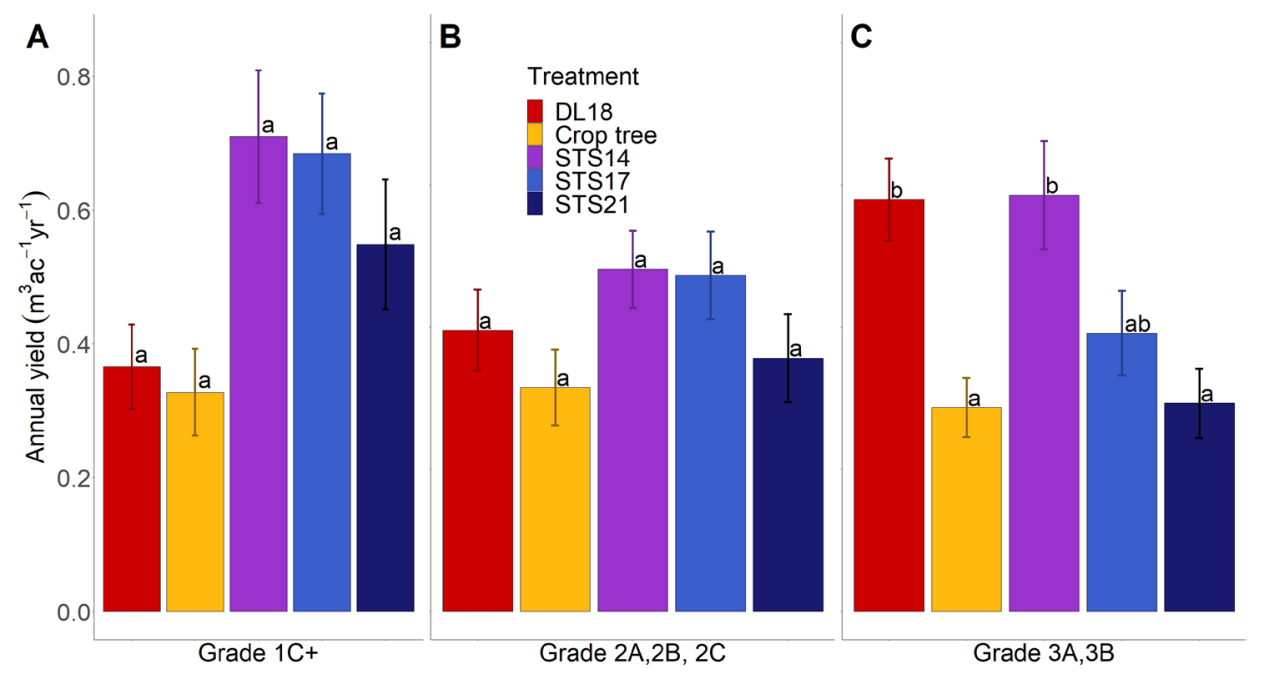

Figure 3.4 Argonne EF average annual dry factory grade sawn lumber yield since 1972 (estimated following Hanks (1976), $\mathrm{m}^{3} \mathrm{ha}^{-1} \mathrm{yr}^{-1}$ ) by grade. Panels A-C for grades 1-3, respectively. Grade $1 \mathrm{C}+$ includes selects and better. Within each graph $(\mathrm{A}, \mathrm{B}, \mathrm{C})$ bars with the same letter are not significantly different, $p<0.05, n=15$. Conversion to cubic meters following Winn et al. 2020. 


\subsubsection{Quality and economics}

MFV was maximized by the STS14 treatment at all discount rates, closely followed by the STS17 treatment (Table 3.5). The DL18 treatment is not competitive under MFV. $\mathrm{PW}$ is the discounted sum of total revenue and MFV, and ranking as evaluated by $\mathrm{PW}$ shows that at lower discount rates such as 2 and 4\%, the STS14 and STS17 perform best (Table 3.5). But as discount rate increases to 6 or $8 \%$, the DL18 treatment surpasses all selection treatments. The STS21 and crop tree treatments performed poorest at all discount rates.

Table 3.5 Financial analysis of Argonne EF treatments, with potential dry factory grade lumber yields valued at price in current 2018 dollars. Present worth is discounted to study start in 1952.

\begin{tabular}{ccccccc}
\hline & DL18 & Crop tree & STS14 & STS17 & STS21 \\
\cline { 2 - 7 } $\begin{array}{c}\text { Periodic Return }\left(\$ \cdot \text { ha }^{-1}\right)^{\mathrm{a}} \\
\begin{array}{c}\text { Mean Treatment Interval } \\
\text { (years) }\end{array}\end{array}$ & 6889 & 1744 & 2910 & 2532 & 1981 \\
& $2 \%$ & 5703 & 5941 & 13287 & 11599 & 9046 \\
\hline \multirow{3}{*}{ MFV $\left(\$ \cdot \text { ha }^{-1}\right)^{\mathrm{c}}$} & $4 \%$ & 1812 & 2623 & 6059 & 5289 & 4125 \\
& $6 \%$ & 742 & 1540 & 3679 & 3212 & 2505 \\
& $8 \%$ & 332 & 1014 & 2511 & 2192 & 1709 \\
& & & & & & \\
& $2 \%$ & 9426 & 7000 & 12876 & 12305 & 9037 \\
& $4 \%$ & 5754 & 3946 & 5847 & 6049 & 4162 \\
& $6 \%$ & 4648 & 3002 & 3723 & 4124 & 2686 \\
& $8 \%$ & 4188 & 2558 & 2776 & 3250 & 2027 \\
\hline
\end{tabular}

aPeriodic return is averaged yearly revenue from $1972-2012$ multiplied by number of years in treatment interval.

${ }^{b}$ Treatment interval is the average of the cutting cycles lengths associated with harvests between 1972 - 2012, except for the $18 \mathrm{~cm}$ DL where it is the interval between the only two harvests in entire study period.

${ }^{\mathrm{c}}$ Calculations assume sustainable stand structure was reached in 1972. 
In 2016, the STS14 treatment had the highest percent of grade 1 standing sawtimber trees $(47.2 \%)$, the lowest amount of below-grade trees at $0 \%$, and the highest average grade (Table 3.6; Table 3.7). The STS17 had similar percentages of grade 1 and below-grade trees, but had greater amounts of grade 3 than the STS14. The control and DL18 treatments had greater percentages of below-grade trees in 2016 (Table 3.7, Figure 3.5). The greatest gains in individual tree grade throughout the past 44 years were also seen under the STS14 treatment, with the least increases in grade found in the STS21 and control (Table 3.6). The greatest amounts of the highest quality sawtimber produced were seen in the STS14 and STS17 (Figure 3.4).

Table 3.6 For trees $>24 \mathrm{~cm}$ dbh at the Argonne EF, average tree grades in 1972 and 2016 , and average increase in grade of individual trees from $1972-2016$. Grade scale from Hanks (1976), sawtimber grades 1-3 with below grade assigned a value of 4 . In the DL18 treatment there were no survivor trees from 1972 to 2016. Standard error in parentheses, $n=15$. Means in a column followed by the same letter are not significantly different, $p<0.05$.

\begin{tabular}{cccc}
\hline Treatment & 1972 & 2016 & $\Delta$ grade \\
\hline STS14 & $2.54(.119) a$ & $1.69(.115) a$ & $1.36(.125) a$ \\
STS17 & $2.62(.097) a$ & $1.89(.113) a b$ & $0.97(.331) a$ \\
Crop tree & $2.82(.106) a b$ & $2.13(.135) a b$ & $0.86(.193) a$ \\
STS21 & $2.54(.108) a$ & $2.14(.133) a b$ & $0.69(.211) a$ \\
Control & $3.04(.086) a b$ & $2.61(.061) b c$ & $0.51(.080) a$ \\
DL18 & $3.33(.106) b$ & $3.20(.072) c$ & --- \\
\hline
\end{tabular}

Table 3.7 For trees $>24 \mathrm{~cm}$ dbh at the Argonne EF, average proportion of trees in each grade as measured in 2016, following Hanks (1976).

\begin{tabular}{ccccc}
\hline Treatment & G1 & G2 & G3 & BG \\
\hline STS14 & 47.2 & 36.1 & 16.7 & 0 \\
STS17 & 45.9 & 21.1 & 30.8 & 2.2 \\
STS21 & 34.9 & 26.1 & 28.7 & 10.3 \\
Crop tree & 29.0 & 33.0 & 34.3 & 3.7 \\
Control & 17.2 & 26.9 & 34.0 & 22.0 \\
DL18 & 0 & 7.7 & 64.3 & 28.0 \\
\hline
\end{tabular}




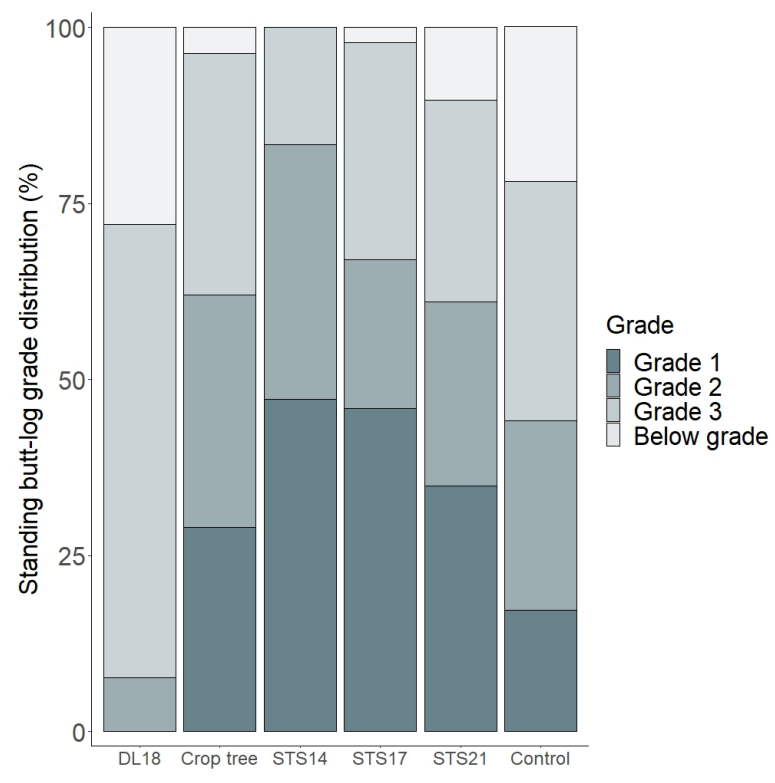

Figure 3.5 For trees $>24 \mathrm{~cm}$ dbh at the Argonne EF, average proportion of trees in each grade as measured in 2016, following Hanks (1976).

\subsubsection{Structure and composition}

Initial stand conditions in 1951 in all treatments were similar, with size class distributions typical for a young, pole-sized even-aged forest with few remnant trees (Figure 3.6). There were very few trees above $50 \mathrm{~cm} \mathrm{dbh}$, and only small differences in average diameter between treatments pre-harvest in 1951 (Figure 3.6A; Table 3.1) One treatment entry was enough to create significant differences in average diameter between treatments by measurement post-harvest in 1952 (Table 3.1). By 1992, post-harvest, the cohort of initially pole-sized trees had moved into the smaller sawtimber size classes (Figure 3.6B). The DL18 treatment had by far the most trees in the $15-\mathrm{cm}$ diameter class in 1992, and all selection treatments had below 37 stems per ha in the $15-\mathrm{cm}$ diameter class.

In 2016, after 65 years of management, average diameter was greatest in the control and STS21, and smallest in the STS14 and DL18 treatments (Table 3.1). The STS14 had a lower, although not significantly different, average diameter than all other selection treatments, as well as the greatest amount of trees in the $15-\mathrm{cm}$ diameter class (Figure 3.6C; Table 3.1). The STS21 and STS17 had trees above $66 \mathrm{~cm}$ dbh, whereas the STS14 did not. 
All treatments were sugar maple-dominated at pre-harvest in 1951. Overstory sugar maple abundance increased from 1951 to 2011 in all treatments except for the DL18 and STS17 (Table 3.8). The greatest increases were seen in the crop tree and STS21, with the least in the STS14. Shannon's diversity index (H') decreased in all treatments except for the crop tree and diameter-limit treatment, with the greatest decrease in the control (Table $3.8)$.

Table 3.8 Relative species abundance and diversity for trees $>11.4 \mathrm{~cm} \mathrm{dbh}$ at the Argonne EF, pre-treatment in 1951 and pre-harvest in 2011.

\begin{tabular}{|c|c|c|c|c|c|c|c|c|c|c|c|}
\hline $\begin{array}{c}\text { Treatm } \\
\text { ent }\end{array}$ & Year & $\begin{array}{c}\text { Acer } \\
\text { saccha } \\
\text { rum }\end{array}$ & $\begin{array}{c}\text { Acer } \\
\text { rubru } \\
m\end{array}$ & $\begin{array}{c}\text { Betula } \\
\text { allegh } \\
\text { aniens } \\
\text { es } \\
\end{array}$ & $\begin{array}{c}\text { Fraxin } \\
\text { us } \\
\text { americ } \\
\text { ana } \\
\end{array}$ & $\begin{array}{c}\text { Ostrya } \\
\text { virgini } \\
\text { ana }\end{array}$ & $\begin{array}{c}\text { Tilia } \\
\text { americ } \\
\text { ana }\end{array}$ & $\begin{array}{l}\text { Tsuga } \\
\text { canad } \\
\text { ensis }\end{array}$ & $\begin{array}{c}\text { Ulmus } \\
\text { americ } \\
\text { ana }\end{array}$ & Other $^{\mathrm{a}}$ & $\begin{array}{c}\text { H' } \\
\text { (Shan } \\
\text { non's } \\
\text { index) }\end{array}$ \\
\hline \multirow{3}{*}{ STS14 } & 1951 & .70 & .06 & .06 & .03 & .03 & .05 & .04 & .00 & .03 & 1.30 \\
\hline & 2011 & .73 & .03 & .03 & .14 & .03 & .04 & .00 & .00 & .00 & 1.05 \\
\hline & $\Delta$ & +.03 & -.03 & -.03 & +.09 & 0 & -.01 & -.04 & 0 & -.03 & -.25 \\
\hline \multirow{3}{*}{ STS17 } & 1951 & .57 & .04 & .06 & .07 & .04 & .08 & .04 & .03 & .07 & 1.74 \\
\hline & 2011 & .56 & .02 & .05 & .11 & .12 & .11 & .01 & .00 & .01 & 1.48 \\
\hline & $\Delta$ & -.01 & -.02 & -.01 & +.04 & +.08 & +.03 & -.03 & -.03 & -.06 & -.26 \\
\hline \multirow{3}{*}{ STS21 } & 1951 & .51 & .01 & .17 & .07 & .04 & .13 & .06 & .01 & .01 & 1.62 \\
\hline & 2011 & .61 & .02 & .06 & .10 & .03 & .17 & .01 & .00 & .01 & 1.39 \\
\hline & $\Delta$ & +.10 & +.01 & -.11 & +.03 & -.01 & +.04 & -.05 & -.01 & 0 & -.23 \\
\hline \multirow{3}{*}{ DL18 } & 1951 & .65 & .01 & .04 & .08 & .02 & .08 & .09 & .00 & .02 & 1.38 \\
\hline & 2011 & .55 & .03 & .01 & .13 & .06 & .01 & .00 & .18 & .02 & 1.51 \\
\hline & $\Delta$ & -.10 & +.02 & -.03 & +.05 & +.04 & -.07 & -.09 & +.18 & 0 & +.13 \\
\hline \multirow{3}{*}{$\begin{array}{l}\text { Crop } \\
\text { tree }\end{array}$} & 1951 & .52 & .10 & .04 & .04 & .05 & .09 & .07 & .03 & .06 & 1.39 \\
\hline & 2011 & .71 & .04 & .01 & .06 & .02 & .10 & .01 & .03 & .03 & 1.60 \\
\hline & $\Delta$ & +.19 & -.06 & -.03 & -.02 & -.03 & +.01 & -.06 & 0 & -03 & +.21 \\
\hline \multirow{3}{*}{ Control } & 1951 & .59 & .06 & .05 & .06 & .03 & .15 & .02 & .03 & .02 & 1.53 \\
\hline & 2011 & .65 & .07 & .04 & .05 & .00 & .17 & .03 & .00 & .00 & 1.22 \\
\hline & $\Delta$ & +.06 & -.01 & -.01 & -.01 & -.03 & -.02 & -.01 & -.03 & -.02 & -.31 \\
\hline
\end{tabular}

${ }^{a}$ Other may include one or more of: Betula papyifera, Fagus grandifolia, Prunus serotina, Fraxinus nigra, Populus tremuloides, Quercus rubra, Abies balamea. 

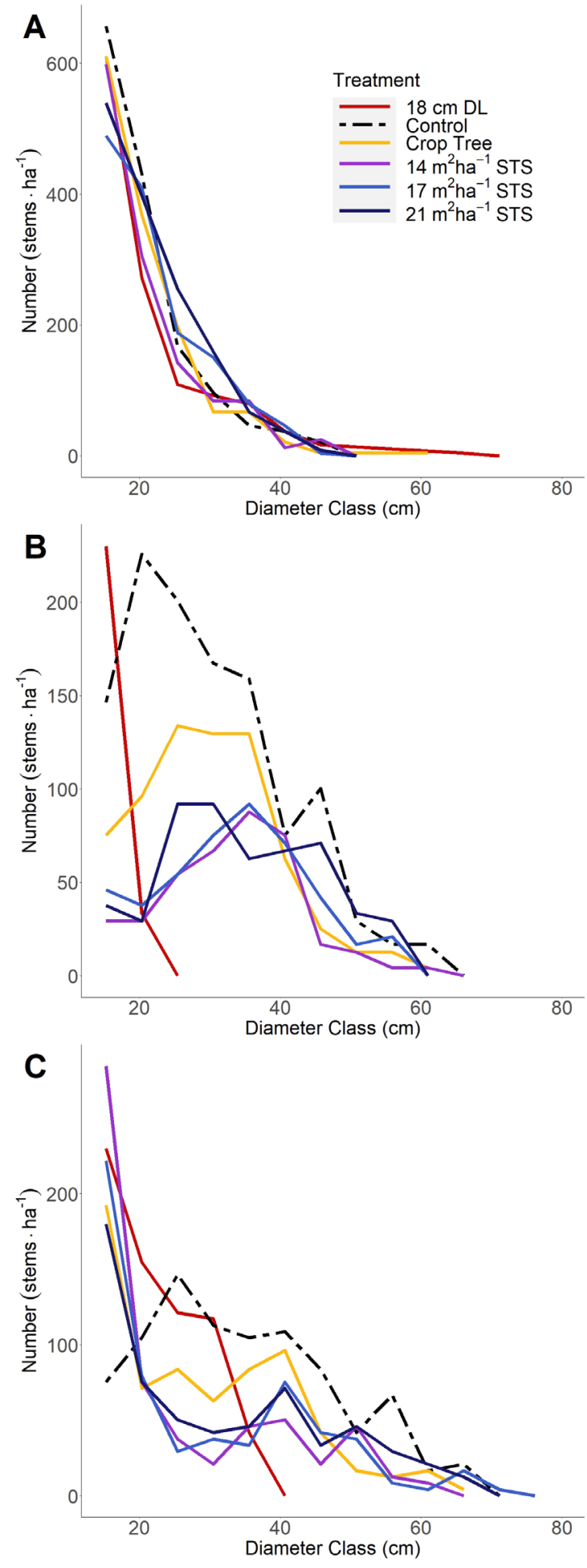

Figure 3.6 Argonne EF stand structure through time for trees $>12.4 \mathrm{~cm} \mathrm{dbh}$. At commencement of study (A, 1951, pre-harvest), at time of last analysis (B, 1992, postharvest), and at most recent measurement (C, 2016, 4-years post-harvest). 
Table 3.9 Mean squares for analysis of variance of diameter, merchantable height, grade, grade proportions, annual ingrowth, and annual mortality at the Argonne EF. * = significance at $\mathrm{p}<0.05, * *=$ significance at $\mathrm{p}<0.01, * * *$ significant at $\mathrm{p}<0.001, \mathrm{~ns}=$ not significant.

\begin{tabular}{|c|c|c|c|c|}
\hline \multirow[t]{2}{*}{ Variable } & \multicolumn{4}{|c|}{ Source of Variation } \\
\hline & Block & Treatment & $\begin{array}{c}\text { Experimental } \\
\text { error }\end{array}$ & $\begin{array}{c}\text { Sampling } \\
\text { error }\end{array}$ \\
\hline df & 2 & 5 & 10 & 72 \\
\hline diameter 1951 & $83.9 *$ & 8.6 & 18.2 & 4.9 \\
\hline diameter 1952 & $69.8^{*}$ & 79.5 & 15.3 & 4.3 \\
\hline diameter 2016 & $278.1^{* *}$ & $315.7 * * *$ & 23.7 & 15.7 \\
\hline diameter growth & $126.9^{*}$ & $266.1 * *$ & 27.3 & 10.3 \\
\hline merch height 1972 & 0.21 & 0.23 & 0.11 & 0.05 \\
\hline merch height 2016 & 0.62 & $2.45^{* * * *}$ & 0.19 & 0.09 \\
\hline grade 1972 & 0.08 & $1.52 *$ & 0.31 & 0.14 \\
\hline grade 2016 & 0.49 & $4.48 * *$ & 0.13 & 0.13 \\
\hline grade increase & 1.98 & 1.32 & 0.93 & 0.55 \\
\hline total annual ingrowth & $0.007 * *$ & $0.026 * * *$ & 0.001 & 0.001 \\
\hline total annual mortality & 0.007 & $0.097 * * *$ & 0.002 & 0.006 \\
\hline $\mathrm{df}^{\mathrm{a}}$ & 2 & 4 & 8 & 60 \\
\hline total annual removals $\mathrm{a}$ & $0.14^{*}$ & $0.11 *$ & 0.02 & 0.01 \\
\hline annual $1 \mathrm{C}+$ yield $^{\mathrm{a}}$ & 12.9 & 42.2 & 15.3 & 8.8 \\
\hline annual $2 \mathrm{~A}, 2 \mathrm{~B}$, and $2 \mathrm{C}$ & & & & \\
\hline yield $^{\mathrm{a}}$ & $33.9^{* *}$ & 7.1 & 3.0 & 3.8 \\
\hline annual $3 \mathrm{~A}$ and $3 \mathrm{~B}$ yield ${ }^{\mathrm{a}}$ & 5.39 & $29.6 * *$ & 3.8 & 4.7 \\
\hline
\end{tabular}




\subsection{Discussion}

In northern hardwoods, financial return is influenced by tree quality (Reed et al. 1987; Sendak et al. 2000). Grade improvements result in the greatest increases in monetary value, more so than growth in diameter or height (Godman and Mendel 1978). The treatments which continually produce high-quality sawtimber while also increasing quality of residuals were thus expected to perform best financially. Single-tree selection is known to increase quality of both harvested and residual trees (Brown et al. 2018; Leak and Sendak 2002), and lower residual basal areas have been seen to produce higher quality trees (Erickson et al. 1990). Thinning is known to positively affect residual timber size and quality, and in long-term studies has increased species diversity, regeneration, and structural development (Zeide 2001; Curtis et al. 1997). Previous long-term studies at the Argonne EF (Niese et al. 1995; Strong et al. 1995) found that a medium selection treatment to $17 \mathrm{~m}^{2} \mathrm{ha}^{-1}$ residual basal area had the greatest increase in quality over 40 years, but the heavy selection treatment to $14 \mathrm{~m}^{2} \mathrm{ha}^{-1}$ residual basal area had the highest economic returns.

The additional two decades of treatment captured in this analysis have resulted in a confluence of quality and economic success; the STS14 now has the greatest economic returns as well as greatest gains in individual tree quality. MFV, proportion of residual grade 1 trees in 2016, and average grade 1C and better lumber volume produced are all high in the STS14 and STS17. Managed forest value is a good indication of continuous repeatable return, and since a key feature of selection silviculture is continuous stocking, a measurement like MFV that assesses return under repeated harvest entries of the same treatment is extremely applicable when evaluating selection and other partial cutting treatments. The financial performance of the STS14 and STS17 under MFV at all discount rates thus indicates success on an ongoing basis, as well as substantial future financial returns. At lower discount rates, the STS14 and STS17 also have the highest present worth, so both present and future financial returns are maximized by these treatments.

The STS14 and STS17 have outperformed others financially in part because diameter growth greatly affects tree quality (Dey et al. 2017; Webster 2009). As trees become larger they surpass more of the threshold requirements for grade 1 and grade 2 
standards (Hanks 1976), so it follows that both diameter growth and grade increases are optimized by the STS14. The STS17 had the second greatest increase in both quality and diameter for individual survivor trees over the entire study period. Indeed, the ranking of treatments for average diameter growth of individual trees throughout the study period is exactly the same as the ranking for average increase in grade of individual trees since 1972. Greater volume removals in the STS14 boosted the growth rate in the residuals so that more high quality sawtimber could be produced over time. Not only were there greater overall volume removals as a result of the STS14, but more grade 1 and better volume was removed which significantly impacts the financial success of any given treatment. Lower densities in northern hardwood forests are known to improve diameter growth (Eyre and Zillgitt 1953) but selection treatments to 18 to $21 \mathrm{ft}^{2} \mathrm{ac}^{-1}$ are thought to maximize merchantable height (Erdmann 1986) as a consequence of higher stand density improving form. Results from this analysis show that both diameter growth and merchantable height at the most recent measurement were greatest in the STS14, followed closely by the STS17.

However, there is a limit to the gains in quality afforded through diameter growth; the rate of value gains declines in larger trees (Godman and Mendel 1978), and larger trees present a higher chance for damage, decay, or defect (Erickson et al. 1992; Dey et al. 2017; Luley et al. 2009). Quality as assigned by grade is also size dependent, so not all diameter growth is equally comparable; faster growth rates of trees cut prior to reaching grade 1 is not equal to volume growth of trees cut immediately after achieving an assignation to the highest grade. For these reasons maturity in northern hardwoods is a result of economics, not age (Arbogast 1957). In the Lake States there is a particular issue with increasing dark heart as sugar maple trees age (Erickson et al. 1992), which has been shown to be more prevalent in trees with slower growth rates and larger diameters (Kaminski et al. 2019). The greatest gains in value are often seen in trees just entering the sawlog class, plus those in the 31, 36, and 41-cm diameter classes (Power and Havreljuk 2018; Reed and Mroz 1997; Smith and Miller 1987). So once a high-quality tree surpasses these thresholds, the optimal time to harvest is likely before there is an opportunity to decrease in value. The STS14 has produced greater volumes of high-quality sawtimber by removing more of the trees in these size classes, and by holding on to fewer in the largest classes. By 2016 the 
STS14 also had a smaller average diameter than all other selection treatments, decreasing the risk of dark heart or other quality reducing defect.

Despite its success in most metrics that contribute to quality, the structure of the STS14 has not been consistently ideal for single-tree selection silviculture. The application of the uneven-aged selection silvicultural systems without modification to this initially even-aged forest has influenced recruitment and growth, and thus sustainable yield, through time. Past studies (Kelty et al. 2003; Nyland 2001; Bédard et al. 2014) show that conversion from even-aged to uneven-aged forest can be accomplished this way, but doubts have recently been cast on the feasibility of this (Bassil et al. 2019), at least in Great Lakes northern hardwoods. Traditional selection management in an uneven-aged forest is concerned with retaining a specific reverse-J diameter distribution to maintain consistent production (Arbogast 1957). However, in this study after 40 years of management, the post-harvest structure does not resemble a reverse-J. The young, even-aged nature of the initial stand led to increasing volume in both removals and residuals through time, but this may change as the forest matures if the selection system as applied fails to consistently recruit new trees. High levels of ingrowth in the 2000s (results not shown) resemble a second cohort beginning to develop, which can also be seen in the increase of stems in the 15 and 20-cm diameter classes from 1992 - 2016 (Figure 3.6B,C) and in the increase in TPH in all treatments since the early 2000s (Figure 3.2), but this is not a consistent source of ingrowth for the treatments.

By definition silvicultural systems plan for regeneration, and so the practice of applying an uneven-aged single-tree selection silvicultural system to an even-aged forest may need to be re-evaluated in light of the lack of regular ingrowth into smaller size classes that is present in the selection systems evaluated here. Some combination of treatments might be superior; the highest ingrowth levels are seen in the DL18. However, northern hardwoods managed with both uneven-aged and even-aged methods do have more structural complexity than unmanaged second-growth hardwoods (Crow et al. 2002). Diversification of forest structure by acquiring many different size classes and successional types is important for many reasons including forest health, wildlife, and continual 
productivity (Wiedenbeck 2020). Varying stand structure can also help increase overstory diversity (Hanson and Lorimer 2007), which is important in this context because unevenaged management increases the dominance of shade-tolerant trees in Great Lakes northern hardwoods (Crow et al. 2002).

Relatively larger removal of the basal area in a stand can result in greater ingrowth and help mitigate this dominance of shade-tolerant trees (Curzon et al. 2017). There have been concerns about trends towards sugar-maple monoculture under traditional single-tree selection as applied in northern hardwoods (Neuendorff et al. 2007; Angers et al. 2005), and so it is important for future management to recognize that reducing basal area to a greater degree may offset this trend. Including aspects of larger scale disturbance in selection methods could help preserve diversity (Angers et al. 2005), and indeed lower basal areas in selection methods have been associated with higher overstory diversity (Niese and Strong 1992; Strong et al. 1995). In this study, total annual ingrowth was highest in the DL18 and STS14. Sugar maple relative abundance over six decades increased the least in the STS14, and actually decreased by $1 \%$ in the STS17, and by $10 \%$ in the DL18. The presence of mid-tolerant species in a stand has often been seen to increase the economic value of the stand when compared to a stand dominated by shade-tolerant species (Erdmann 1986), helping to offset any financial loss due to comparably lower merchantable height, so there are also financial incentives to strive towards greater overstory species diversity.

Overall, treatments that remove more of the basal area result in a better return on investment. In selection treatments, lower residual basal areas have been found to result in greater residual growth and lower mortality (Forget et al. 2007). Schuler and McGill (2007) found that basal areas of about $12.6 \mathrm{~m}^{2} \mathrm{ha}^{-1}$ may be optimal for increasing periodic sawtimber yield in hardwoods. The STS14 has had consistently the lowest mortality as well as greatest grade 1+ and total volumes harvested. All of these factors contribute to higher economic returns. Moreover, there is an opportunity cost inherent in retaining older trees. Economic return is not realized until volume is removed from a stand and sold. Treatments such as the STS21 that retain a lot of volume, especially in larger trees, are not 
capitalizing on the value of high-quality trees. The ratio of growth to removals in northern hardwood forests has been the highest in the country for many decades, indicating that increased sawtimber removals can be implemented and may benefit forests (Wiedenbeck 2020). However, extremely high volume removals, particularly severe diameter-limit cuts, are not successful in producing high-quality trees or consistent yield and returns. The DL18 ranked last in all assessed quality and growth metrics. Harsh diameter-limit cuts carry other concerns for forest managers as well, such as potential dysgenic effects that can accumulate through time (Buongiorno et al. 2000).

Return on investment and continual financial success are strong incentives for any management method, and so treatments such as the STS14 that encourage ingrowth, lower mortality, improve quality, and perform well financially could be considered as potential alternatives to traditional single-tree selection as it is currently prescribed in northern hardwoods. Such alternatives are being increasingly considered as concerns about the sustainability of the selection system become more prevalent (Campione et al. 2012; Danyagari et al. 2018; Henry et al. 2021; Kern et al. 2014; Matonsis et al. 2011). For example, silvicultural approaches like group selection and gap-based management that incorporate greater levels of disturbance than traditional single-tree selection are being implemented in northern hardwoods, to help increase diversity and desirable regeneration (Kern et al. 2017; Hupperts et al. 2019; Knapp et al. 2019). Alternative silvicultural methods should also incorporate and acknowledge the idea that financial gain drives many management decisions, and so a balance between managing for financial returns (by increasing quality and periodic yield) and ecological concerns (such as increasing structural diversity and species diversity) is often favorable. Considering the results from this analysis, that might comprise a combination of a selection treatment to lower residual basal areas, and a diameter-limit cut, perhaps less harsh than the DL18. Management recommendations in line with this idea have been previously expressed in past studies; medium-intensity diameter-limit cuts with improvement are suggested by Buongiorno et al (2000) and Smith and Miller (1987), and financial-maturity diameter-limit treatments have been used as a variant on the selection system to combine silvicultural considerations with financial concerns (Trimble et al. 1974; Schuler and McGill 2007). 


\section{Reference List}

Angers, V.A., C. Messier, M. Beaudet, and A. Leduc. 2005. Comparing composition and structure in old-growth and harvested (selection and diameter-limit cuts) northern hardwood stands in Quebec. For. Ecol. Manag. 217(2-3):275-293.

Arbogast, C.J. 1957. Marking Guides for Northern Hardwoods under the Selection System. USDA Forest Service Station Pap. LS-56, Lake States Forest Experiment Station, St. Paul, MN. 20 p.

Bassil, S., R.D. Nyland, C.C. Kern, and L. Kenefic. 2019. Dynamics of the diameter distribution after selection cutting in uneven-aged and even-aged northern hardwood stands: a long-term evaluation. Can. J. For. Res. 49(12):525- 539.

Bates, D., M. Maechler, B. Bolker, S.Walker. 2015. Fitting Linear Mixed-Effects Models Using lme4. Journal of Statistical Software. 67(1): 1-48.

Bédard, S., F. Guillemette, P. Raymond, S. Tremblay, C. Larouche, and J. DeBlois. 2014. Rehabilitation of northern hardwood stands using multicohort silvicultural scenarios in Québec. J. of For. 112(3):276-286.

Bodine, J. T. 2000. The effects of eight silvicultural treatments on quality development financial returns and regeneration following 42 years of management. M.Sc. thesis, Michigan Tech. Univ., MI, Unites States of America. 73 p.

Bohn, K.K., R. D. Nyland, and R.D. Yanai. 2011. Comparing selection system and diameter-limit cutting in uneven-aged northern hardwoods using computer simulation. Can. J. For. Res. 41(5):963-973.

Bourdo, E.A. 1957. Plan for the establishment of 1956 stocking level management studies in 'selectively cut' northern hardwoods and a brief outline of associated terminal studies. Ford Forestry Center, Michigan Tech. Univ., MI. 14 p.

Brown, J.P., M.A. Thomas-Van Gundy, T.M. Schuler, and J.L. Wiedenbeck. 2018. Silvicultural prescriptions influence the proportion of high-quality butt logs harvested over a half-century of management. For. Sci. 64(2):203-213. 
Buongiorno, J., A. Kolbe, and M. Vasievich. 2000. Economic and ecological effects of diameter-limit and $\mathrm{BDq}$ management regimes: simulation results for northern hardwoods. Silva Fenn. 34(3): 223-235.

Burger, T. L. and J. Kotar. 2003. A guide to forest communities and habitat types of Michigan. University of Wisconsin-Madison, Madison, WI. 361 p.

Campione, M.A., L.M. Nagel, and C.R. Webster. 2012. Herbaceous-layer community dynamics along a harvest-intensity gradient after 50 years of consistent management. Open J. For. 2(3):97-109.

Crow, T.R., D.S. Buckely, E.A Nauertz, and J.C. Zasada. 2002. Effects of management on the composition and structure of northern hardwood forests in Upper Michigan. For. Sci. 48(1):129-145.

Curtis, R.O., D. D. Marshall, and J.F. Bell. 1997. A pioneering example of silvicultural research in coast Douglas-fir. J. For. 95(7):19-25.

Curzon, M.T., A.W. D'Amato, S. Fraver, B.J. Palik, A. Bottero, J.R. Foster, and K.E. Gleason. 2017. Harvesting influences functional identity and diversity over time in forests of the northeastern USA. For. Ecol. Manag. 400:93-99.

D’Amato, A.W., J. Bradford, S. Fraver, and B. Palik. 2011. Forest management for mitigation and adaptation to climate change: Insights from long-term silviculture experiments. For. Ecol. Manag. 262(5):803-816.

Danyagri, G., S.K. Baral, and G. Pelletier. 2019. Effects of disturbance and site factors on sapling dynamics and species diversity in northern hardwood stands. For. Ecol. Manag. (444):225-234.

Dey, D.C., J. Dwyer, and J. Wiedenbeck. 2017. Relationship between tree value, diameter, and age in high-quality sugar maple (Acer saccharum) on the Menominee Reservation, Wisconsin. J. For. 115(5):397-405.

Erdmann, G.C. 1986. Developing quality in second-growth stands. P. 206-222 in Proc., The northern hardwood resources: Management and potential, Mroz, G.D., and D.D. Reed (comps.). Michigan Tech. Univ., Houghton, MI. 
Erdmann, G.G. and R.R. Oberg. 1973. Fifteen-year results from six cutting methods in second-growth northern hardwoods. USDA Forest Service Res. Pap. NC-100, North Central Forest Experiment Station, St. Paul, MN. 12 p.

Erickson, M., D. Reed, and G. Mroz. 1990. Stand development and economic analysis of alternative cutting methods in northern hardwoods: 32-year results. North. J. Appl. For. 7(4):53-158.

Erickson, M., G. Mroz, and D. Reed. 1992. Silvicultural influence on heartwood discoloration in sugar maple. North. J. Appl. For. 9(1):27-29.

Eyre, F. H., and W.M. Zillgitt. 1953. Partial cuttings in northern hardwoods of the Lake States USDA Forest Service Tech. Bulletin No. 1076, North Central Forest Experiment Station, St. Paul, MN. 124 p.

Fajvan, M.A. 2006. Research on diameter-limit cutting in central Appalachian forests. P 32-38 in Proceedings of the Conference on Diameter-Limit Cutting on Northeastern Forests, L.S. Kenefic and R.D. Nyland (eds). USDA Forest Service Gen. Tech. Rep. NE-342, Northeastern Research Station, Newtown Square, PA. 51 p.

Forget, E., P. Nolet, F. Doyon, S. Delagrange, and Y. Jardon. 2007. Ten-year response of northern hardwood stands to commercial selection cutting in southern Quebec, Canada. For. Ecol. Manag. 242(2-3):764-775.

Gevorkiantz, S.R. and L.P. Olsen. 1955. Composite volume tables for timber and their application in the Lake States. USDA Forest Service Tech. Bulletin No. 1104, Lake States Forest Experiment Station, St. Paul, MN. 51 p.

Gilbert, A.M. and V.S. Jensen. 1958. A management guide for northern hardwoods in New England. USDA Forest Service Station Pap. NE-112, Northeastern Forest Experiment Station, Upper Darby, PA. 22 p.

Godman, R.M. and D.J. Brooks. 1971. Influence of stand density on stem quality in polesize northern hardwoods. USDA Forest Service Res. Pap. MC-54, North Central Forest Experiment Station, St. Paul, MN. 7 p. 
Godman, R.M. and J.J. Mendel. 1978. Economic values for growth and grade changes of sugar maple in the Lake States. USDA Forest Service Res. Pap. MC-155, North Central Forest Experiment Station, St. Paul, MN. 16 p.

Gronewold, C.A., A.W. D'Amato, and B.J. Palik. 2010. The influence of cutting cycle and stocking level on the structure and composition of managed old-growth northern hardwoods. For. Ecol. Manag. 259(6):1151-1160.

Gustafson, E.J., CC. Kern, B.R. Miranda, B.R. Sturtevant, D.R. Bronson, and J.M Kabrick. 2020. Climate adaptive silviculture strategies: How do they impact growth, yield, diversity and value in forested landscapes?. For. Ecol. Manag. 470: 118-208.

Hanks, L.F. 1976. Hardwood log grades and lumber grade yields for factory lumber logs. USDA Forest Service Res. Pap. NE-333, Northeastern Forest Experiment Station, Upper Darby, PA. 81 p.

Hanson, J.J. and C.G. Lorimer. 2007. Forest structure and light regimes following moderate wind storms: Implications for multi-cohort management. Ecol. Appl. 17(5):1325-1340.

Hawley, G.J., P.G.Schaberg, DeHayes, D.H., and J.C. Brissette. 2005. Silviculture alters the genetic structure of an eastern hemlock forest in Maine, USA. Can. J. For. Res. 35(1):143-150.

Henry, C.R., M. B. Walters, A.O. Finley, G.J. Roloff, and E.J. Farinosi. 2021. Complex drivers of sugar maple (Acer saccharum) regeneration reveal challenges to long-term sustainability of managed northern hardwood forests. For. Ecol. Manag. 479:118541.

Howe, G.E. 1989. Genetic effects of even-aged and uneven-aged silviculture. P 84-91 in Proceedings of the National Silviculture Workshop: Silvicultural Challenges and Opportunities in the 1990s. USDA Forest Service Timber Management Workshop, Petersburg, AK. 216 p.

Hupperts, S.F., Y.L. Dickinson, C.R. Webster, and C.C. Kern. 2019. Promoting structural and species diversity in Great Lakes northern hardwoods: a conceptual model and its application. Forestry . 92(1):16-25.

Johnson, J.A. 1984. Small-woodlot management by single-tree selection: 21-year results. North. J. Appl. For. 1(4):69-71. 
Kaminski, J., M. Demchik, and N. Timilsina. 2019. Factors Relating to Dark Heart of Sugar Maple in Wisconsin. J. For. 117(3):256-266.

Kelty, M.J., D.B. Kittredge Jr., T. Kyker-Snowman, and A.D. Leighton. 2003. The conversion of even-aged stands to uneven-aged structure in southern New England. North. J. Appl. For. 20(3):109-116.

Kenefic, L.S. and C.C. Kern. 2013. The remarkable story of the partial cutting study at the Dukes Experimental Forest. P. 116-125 in Long-term silvicultural and ecological studies. Results for science and management, Ann E. Camp, L.C. Irland, and C. J.W. Carroll. GISF Research Paper 013. Global Institute of Sustainable Forestry, Yale University, New Haven, CT.

Kenefic, L.S., and R.D. Nyland. 2005. Diameter-limit cutting and silviculture in northeastern forests: A primer for landowners, practitioners, and policymakers. USDA Forest Service NA-TP02-05, Northeast Area State and Private For., Newton Square, PA. 18 p.

Kenefic, L.S., P.E. Sendak, and J.C. Brissette. 2005. Comparison of fixed diameter-limit and selection cutting in northern conifers. North. J. Appl. For. 22(5):77-84.

Kern, C.C., G. Erdmann, L. Kenefic, B. Palik, and T. Strong. 2014. Development of the selection system in northern hardwood forests of the Lake States: An 80-year silviculture research legacy. P. 201-223 in USDA Forest Service experimental forests and ranges research for the long term, D.C. Hayes, S.L. Stout, R.H. Crawford, and A.P. Hoover (eds.). Springer, New York, NY.

Kern, C.C., J.I. Burton, P. Raymond, A.W. D'Amato, W.S. Keeton, A.A. Royo, M.B. Walters, C.R. Webster, and J.L. Willis. 2017. Challenges facing gap-based silviculture and possible solutions for mesic northern forests in North America. Forestry: Int. J. of For. Res. 90(1):4-17.

Keuhl, R. 2000. Treatment Comparisons. P 73-122 in Design of Experiments: Statistical Principles of Research Design and Analysis Second Edition. Brooks/Cole, Pacific Grove, California, USA. 
Knapp, S.P., C.R. Webster, and C.C. Kern. 2019. Can group selection with legacy retention change compositional trajectories in conventionally managed hardwoods? For. Ecol. Manag. 448:174-186.

Kotar, J., T.L. Burger, and J.A. Kovach. 2002. A guide to forest communities and habitat types of northern Wisconsin. University of Wisconsin-Madison, Department of Forestry Ecology and Management.

Leak, W.B. 1996. Long-term structural change in uneven-aged northern hardwoods. For. Sci. 42(2):160-165.

Leak, W.B. 2007. Thinning northern hardwoods in New England by dominant-tree removal—early results. N. J. Appl. For. 24(4):312-313.

Leak, W.B. and P.E. Sendak. 2002. Changes in species, grade, and structure over 48 years in a managed New England northern hardwood stand. North. J. Appl. For. 19(1): 2527.

Leak, W.B., D.S. Solomon, and P.S. DeBald. 1987. Silvicultural guide for northern hardwood types in the Northeast (revised). USDA Forest Service Res. Pap. NE-603, Northeastern Forest Experiment Station, Broomall, PA. 36 p.

Leak, W.B., M. Yamasaki, and R. Holleran. 2014. Silvicultural guide for northern hardwoods in the northeast. USDA Forest Service Gen. Tech. Rep. NRS-132. Northern Research Station, Newtown Square, PA. 46 p.

Lenth, R. 2020. emmeans: Estimated Marginal Means, aka Least-Squares Means. R package version 1.4.7. https://CRAN.R-project.org/package=emmeans

Luley, C.J., D.J. Nowak, E.J. Greenfield. 2009. Frequency and severity of trunk decay in street tree maples in four New York cities. Arbor. Urb. For. 35(2): 94-99.

Luppold, W.G., J.P. Prestemon, and J.E. Baumgras. 2001. A long-term analysis of hardwood lumber prices. Proceedings in 2000 annual meeting of the Southern Forest Economic Workers. 149-154.

Lussier, J.M., 2009. Changing our mental model from growing volume to producing value: The case of uneven-aged hardwood management. For. Chronicle. 85(3):382-386. 
Martin, A.J. and M. Luedeke. 1989. How to evaluate forestry investments. Vol. 3476. Department of Agricultural Journalism, University of Wisconsin-Extension, Madison, WI. 14 p.

Matonis, M. S., M. B. Walters, and J.D. Millington. 2011. Gap-, stand-, and landscapescale factors contribute to poor sugar maple regeneration after timber harvest. For. Ecol. Manag. 262(2):286-298.

Michigan DNR. Stumpage price reports. Available online at http://www.michigandnr.com/ftp/forestry/tsreports/StumpagePriceReports/; last accessed Apr. 20, 2020.

Miller, G.W. 1991. Practicing uneven age management: does it pay? Some economic considerations. P. 47-63 in Proceedings: uneven aged management of hardwoods in the Northeast, Mark C. Vodak (ed.). Rutgers University, New Brunswick, NJ.

Miller, G.W. 1993. Financial aspects of partial cutting practices in central Appalachian hardwoods. USDA Forest Service Res. Pap. NE-673, Northeastern Forest Experiment Station, Radnor, PA. 9 p.

Moreau, G., A. Achim, and D. Pothier. 2020. Growth and survival dynamics of partially cut northern hardwood stands as affected by precut competition and spatial distribution of residual trees. Forestry. 93(1):96-106.

Neuendorff, J. K., L.M. Nagel, C.R. Webster, and M.K. Janowiak. 2007. Stand structure and composition in a northern hardwood forest after 40 years of single-tree selection. North. J. Appl. For. 24(3): 197-202.

Niese, J. N., T.F. Strong, and G.G. Erdmann. 1995. Forty years of alternative management practices in second-growth, pole-size northern hardwoods: Economic evaluation. Can. J. For. Res. 25(7):1180-1188.

Niese, J.N. and T.F. Strong. 1992. Economic and tree diversity trade-offs in managed northern hardwoods. Can. J. For. Res. 22(11):1807-1813.

Nyland, R.D. 1988. Past and present silviculture and harvesting practices in central and northern hardwoods. P 21-39 in $31^{\text {st }}$ Northeast Forest Tree Improvement Conference 
and 6th Forest Tree Improvement Association Joint Meeting, M.E. Demeritt, Jr. ed. USDA Forest Service NE For. Tree Improve. Conf., Berea, KY.

Nyland, R.D. 1998. Selection system in northern hardwoods. J. For. 96(7):18-21.

Nyland, R.D. 2001. Even-to uneven-aged: the challenges of conversion. For. Ecol. MAnag. 172 (2-3): 291-300.

Nyland, R.D. 2005. Diameter-limit cutting and silviculture: A comparison of long-term yields and values for uneven-aged sugar maple stands. North. J. Appl. For. 22(2):111116.

Nyland, R.D. 2016. Silviculture: Concepts and Applications. Waveland Press, Long Grove, IL. $680 \mathrm{p}$.

O'Hara, K.L. 2002. The historical development of uneven-aged silviculture in North America. Forestry. 75(4):339-346.

Oksanen, J., F. G. Blanchet, M. Friendly, R. Kindt, P. Legendre, D. McGlinn, P. R. Minchin, R. B. O'Hara, G. L. Simpson, P. Solymos, M. H. Stevens, E. Szoecs and H. Wagner. 2019. vegan: Community Ecology Package. R package version 2.5-6. https://CRAN.R-project.org/package=vegan

Orr, B.D., D.D. Reed, and G.D. Mroz. 1994. Three basal area level harvest trials in unevenaged northern hardwoods. North. J. Appl. For. 11(4):117-123.

Pond, N.C. and R.E. Froese. 2015. Interpreting stand structure through diameter distributions. For. Sci. 61(3):429-437.

Pond, N.C., R.E. Froese, and L.M. Nagel. 2014. Sustainability of the selection system in northern hardwood forests. For. Sci. 60(2):374-381.

Power, H. and F. Havreljuk. 2018. Predicting hardwood quality and its evolution over time in Quebec's forests. Forestry. 91(3): 259-270.

Previant, W. 2015. Legacy and opportunity in northern hardwood forests. Ph.D. Thesis, Michigan Tech. Univ., MI, Unites States of America. 150 p.

R Core Team. 2020. R: A language and environment for statistical computing. R Foundation for Statistical Computing, Vienna, Austria. URL https://www.Rproject.org/. 
Reed, D.D. and G.D. Mroz. 1997. Rate of sawtimber volume and value growth of individual sugar maple trees in managed, uneven-aged stands in the Lake States. North. J. Appl. For. 14(2): 78-83.

Reed, D.D., G.W. Lyon, and E.A. Jones. 1987. A method for estimating log grade distribution in sugar maple. For. Sci. 33(2):565-569.

Reed, D.D., M.J. Holmes, and J.A. Johnson. 1986. A 22-year study of stand development and financial return in northern hardwoods. North. J. Appl. For. 3(1):35-38.

Rideout, D. 1985. Managerial finance for silvicultural systems. Can. J. For. Res. 15(1):163-166.

Schuler, T.M, and D.W. McGill. 2007. Long-term assessment of financial maturity, diameter-limit selection in the central Appalachians. USDA Forest Service Res. Pap. NRS-2, Northern Research Station, Newtown Square, PA. 16 p.

Schuler, T.M., M. Thomas-Van Gundy, J.P. Brown, and J.K. Wiedenbeck. 2017. Managing Appalachian hardwood stands using four management practices: 60-year results. For. Ecol. Manag. 387:3-11.

Sendak, P.E., W.B. Leak, and W.B. Rice. 2000. Hardwood tree quality development in the White Mountains of New Hampshire. North. J. Appl. For. 17(1):9-15.

Smith, H.C. and G.W. Miller. 1987. Managing Appalachian Hardwood Stands Using Four Regeneration Practice - 34-Year Results. North. J. Appl. For. 4(4):180-185.

Soil Conservation Service. 1988. Soil survey of Baraga County are Michigan. USDA Soil Conserv. Serv. 306 p.

Sonderman, D.L. 1985. Stand density--a factor affecting stem quality of young hardwoods. USDA Forest Service Res. Pap. NE-561, Northeastern Forest Experiment Station, Broomall, PA. 8 p.

Stoeckler, J.H. 1955. Establishment report for cutting methods study (A-3) in pulpwood sized northern hardwoods. USDA Forest Service Report RS-LS, Lake States Forest Experiment Station, St. Paul, MN. 60 p. 
Strong, T.F, G.G Erdmann, J.N. Niese. 1995. Forty Years of alternative management practives in second-growth, pole-size northern hardwoods: Tree quality development. Can. J. For. Res. 25(7):1173-1179.

Trimble, G.R., J.J. Mendel, and R.A. Kennell. 1974. A procedure for selection on marking in hardwoods. USDA Forest Service Res. Pap. NE-292, Northeastern Forest Experiment Station, Upper Darby, PA. 13 p.

Tubbs, C.H. 1977a. Manager's handbook for northern hardwoods in the North Central States. USDA Forest Service Gen. Tech. Rep. NC-39, North Central Forest Experiment Station, St. Paul, MN. 29 p.

Tubbs, C. H. 1977b. Natural regeneration of northern hardwoods in the northern Great Lakes. USDA Forest Service Res. Pap. NC-150, North Central Forest Experiment Station, St. Paul, MN. 18 p.

U.S. Bureau of Labor Statistics. Producer price index by commodity for lumber and wood products. Available online at https://fred.stlouisfed.org/series/WPU08; last accessed Mar. 3, 2020.

U.S. Department of Agriculture Forest Service Northeastern Area State and Private Forestry. 2008. Timber management field book. NA-MR-02-08. Newtown Square, PA. $142 \mathrm{p}$.

U.S. Department of Agriculture Natural Resources Conservation Service. Web Soil Survey. Available online at: http://websoilsurvey.sc.egov.usda.gov/. Last accessed 3 March 2021.

Ulrich, A.H. 1983. US Timber Production, Trade, Consumption, and Price Statistics, 1950-81. USDA Forest Service Publication No. 1424, Washington, D.C. 77 p.

Wagner, J.E., J. Rahn, and M. Cavo. 2019. A Pragmatic Method to Forecast Stumpage Prices. For. Sci. 65(4):429-438.

Webster, C.E., D.D. Reed, B.D. Orr, J.M. Schmierer, and J.B. Pickens. 2009. Expected rates of value growth for individual sugar maple crop trees in the Great Lakes region. North. J. Appl. For. 26(4): 133-140. 
Wiedenbeck, J. and K.T. Smith. 2018. Hardwood management, tree wound response, and wood product value. For. Chron. 94(3): 292-306.

Wiedenbeck, J. 2020. Undervalued hardwood utilization from the forest manager's perspective. P 1-6 in Undervalued hardwoods for engineered materials and components, $2^{\text {nd }}$ ed., R.J. Ross, J.R. Erickson (eds). USDA Forest Service Gen. Tech. Rep. FPL-GTR-276, Forest Products Laboratory, Madison, WI.

Winn, M.F., L.A Royer, J.W Bentley, R.J. Piva, T.A Morgan, E.C. Berg, and J.W. Coulston. 2020. Timber products monitoring: unit of measure conversion factors for roundwood receiving facilities. USDA Forest Service e-Gen. Tech. Rep. SRS-251, Southern Research Station, Asheville, NC. 148 p.

Zeide, B. 2001. Thinning and growth: a full turnaround. J. For. 99(1):20-25.

Zobrist, K. 2014. Financial analysis principles and applications for private forest lands. WSU Extension Manual EM030E. Pullman, WA. 36 p. 


\section{A Summary Information for the Cutting Methods}

\section{Studies}

\section{A.1 Plot Layout Maps}

Figure A.1.1 Ford Forest Study Layout

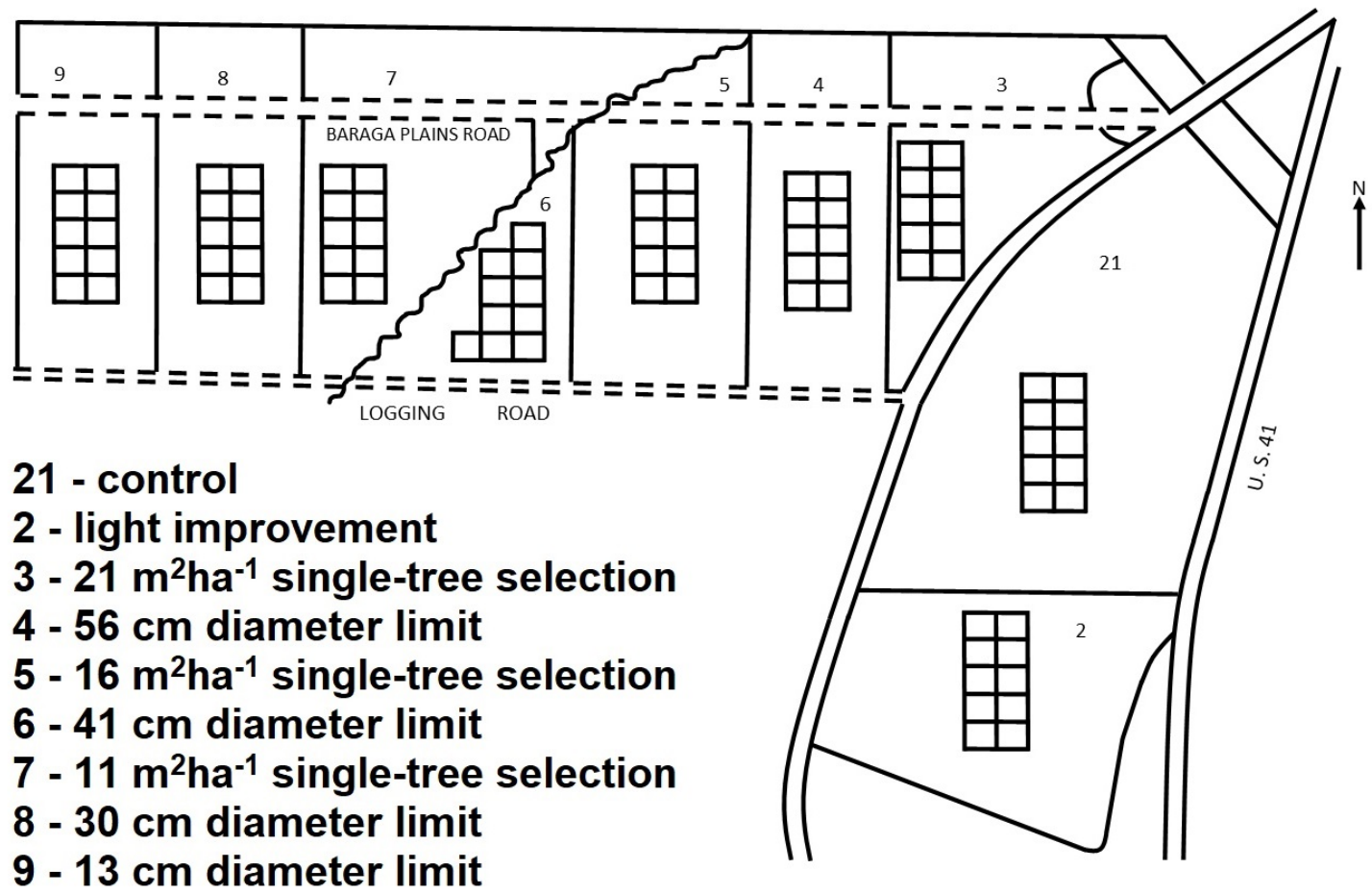

[re-created following Bourdo 1957] 
Figure A.1.2 Argonne Example Treatment Plot

$100.6 \mathrm{~m}$ ( 5 chains)

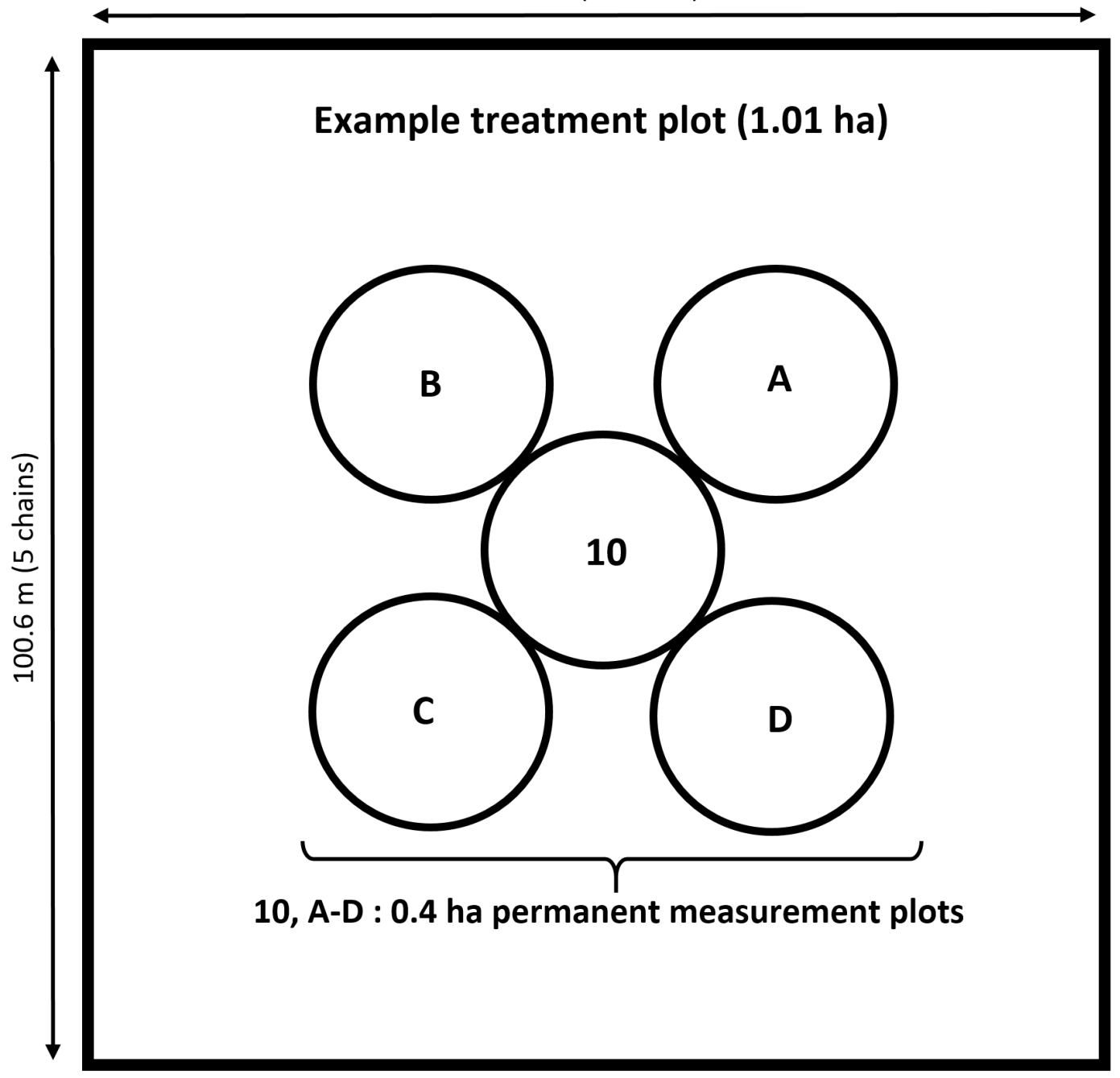

[re-created following Stoeckler 1955] 


\section{A.2 Studies Summary Table}

Table A.2.1 Summary Information

\begin{tabular}{|c|c|c|c|c|c|}
\hline Site & $\begin{array}{c}\text { Treatment } \\
\text { Abbreviation }\end{array}$ & Treatment Description & $\begin{array}{c}\text { Total } \\
\text { Treatment } \\
\text { Unit Area } \\
\text { (ha) }\end{array}$ & $\begin{array}{l}\text { Total } \\
\text { Measurement } \\
\text { Plot Area (ha) }\end{array}$ & Harvest Entry Year ${ }^{a}$ \\
\hline $\begin{array}{l}\text { Ford } \\
\text { Forest }\end{array}$ & LI & $\begin{array}{l}\text { "Light Improvement" } \\
\text { treatment to } 15-16 \mathrm{~m}^{2} \mathrm{ha}^{-1} \\
\text { residual basal area based } \\
\text { on increasing quality. }\end{array}$ & 3 & 0.4 & $\begin{array}{l}1957,1968,1978, \\
1988,1998,2008, \\
2018\end{array}$ \\
\hline $\begin{array}{l}\text { Ford } \\
\text { Forest }\end{array}$ & STS $21^{\mathrm{b}, \mathrm{c}}$ & $\begin{array}{c}\text { Selection system to } 21 \\
\mathrm{~m}^{2} \mathrm{ha}^{-1} \text { residual basal area, } \\
\text { with a } 61 \mathrm{~cm} \text { limiting } \\
\text { diameter and a } q \text {-value of } \\
1.3 .\end{array}$ & 1.7 & 0.4 & $\begin{array}{c}1956,1968,1978 \\
1998,2008\end{array}$ \\
\hline $\begin{array}{l}\text { Ford } \\
\text { Forest }\end{array}$ & STS $16^{\mathrm{b}, \mathrm{c}}$ & $\begin{array}{c}\text { Selection system to } 16 \\
\mathrm{~m}^{2} \mathrm{ha}^{-1} \text { residual basal area, } \\
\text { with a } 61 \mathrm{~cm} \text { limiting } \\
\text { diameter and a } q \text {-value of } \\
1.3 .\end{array}$ & 2.3 & 0.4 & $\begin{array}{l}1956,1968,1978, \\
1988,1998,2008, \\
2018\end{array}$ \\
\hline $\begin{array}{l}\text { Ford } \\
\text { Forest }\end{array}$ & STS $11^{\mathrm{b}, \mathrm{c}}$ & $\begin{array}{c}\text { Selection system to } 11 \\
\mathrm{~m}^{2} \mathrm{ha}^{-1} \text { residual basal area, } \\
\text { with a } 61 \mathrm{~cm} \text { limiting } \\
\text { diameter and a } q \text {-value of } \\
1.3 .\end{array}$ & 2.1 & 0.4 & $\begin{array}{l}1957,1968,1978, \\
1988,1998,2008, \\
2018\end{array}$ \\
\hline $\begin{array}{l}\text { Ford } \\
\text { Forest }\end{array}$ & DL56 $6^{\mathrm{c}}$ & $\begin{array}{l}\text { Cut all trees above a } \\
\text { limiting diameter of } 56 \\
\mathrm{~cm} \text {. Marked strictly based } \\
\text { on dbh with no tending. }\end{array}$ & 1.9 & 0.4 & $\begin{array}{c}1956,1968,1998, \\
2008,2018\end{array}$ \\
\hline $\begin{array}{l}\text { Ford } \\
\text { Forest }\end{array}$ & DL41 ${ }^{\mathrm{c}}$ & $\begin{array}{l}\text { Cut all trees above a } \\
\text { limiting diameter of } 41 \\
\mathrm{~cm} \text {. Marked strictly based } \\
\text { on dbh with no tending. }\end{array}$ & 1.5 & 0.4 & $\begin{array}{l}1956,1968,1978, \\
1988,1998,2008, \\
2018\end{array}$ \\
\hline $\begin{array}{l}\text { Ford } \\
\text { Forest }\end{array}$ & DL30 ${ }^{c}$ & $\begin{array}{l}\text { Cut all trees above a } \\
\text { limiting diameter of } 30 \\
\mathrm{~cm} \text {. Marked strictly based } \\
\text { on dbh with no tending. }\end{array}$ & 2 & 0.4 & $\begin{array}{c}1957,1988,2008, \\
2018\end{array}$ \\
\hline $\begin{array}{c}\text { Ford } \\
\text { Forest }\end{array}$ & DL13 & $\begin{array}{l}\text { Cut all trees above a } \\
\text { limiting diameter of } 13 \\
\mathrm{~cm} \text {. Marked strictly based } \\
\text { on dbh with no tending. }\end{array}$ & 1.9 & 0.4 & 1956,1998 \\
\hline $\begin{array}{l}\text { Ford } \\
\text { Forest }\end{array}$ & control & $\begin{array}{c}\text { Reserve area not } \\
\text { harvested over period of } \\
\text { study. }\end{array}$ & 5.8 & 0.4 & N/A \\
\hline
\end{tabular}

a Harvest usually completed in fall/winter of the stated year

b For harvests 1956-1988 the residual basal area target was applied to trees $25 \mathrm{~cm}$ and above. Starting with the 1998 harvest, the residual target was applied to trees $13 \mathrm{~cm}$ and above.

c A salvage harvest to remove dead and dying Ulmus americana was performed in 1980 in these treatment compartments. 


\begin{tabular}{|c|c|c|c|c|c|}
\hline Site & $\begin{array}{c}\text { Treatment } \\
\text { Abbreviation }\end{array}$ & $\begin{array}{l}\text { Treatment } \\
\text { Description }\end{array}$ & $\begin{array}{c}\text { Total } \\
\text { Treatment } \\
\text { Unit Area } \\
\text { (ha) }\end{array}$ & $\begin{array}{c}\text { Total } \\
\text { Measurement } \\
\text { Plot Area } \\
\text { (ha) }\end{array}$ & $\begin{array}{c}\text { Harvest Entry } \\
\text { Year }^{\mathrm{a}}\end{array}$ \\
\hline $\begin{array}{c}\text { Argonne } \\
\text { EF }\end{array}$ & DL18 & $\begin{array}{c}\text { All trees } 20 \mathrm{~cm} \text { or } \\
\text { larger at a } 30.5 \text { inch } \\
\text { stump height (about } \\
18 \mathrm{~cm} \mathrm{dbh)}\end{array}$ & 3 & 0.6 & 1952,1992 \\
\hline $\begin{array}{c}\text { Argonne } \\
\text { EF }\end{array}$ & STS21 & $\begin{array}{l}\text { Selection system to } \\
21 \mathrm{~m}^{2} \mathrm{ha}^{-1} \text { residual } \\
\text { basal area, with a } 61 \\
\mathrm{~cm} \text { limiting } \\
\text { diameter and a } q- \\
\text { value of } 1.3 \text {. }\end{array}$ & 3 & 0.6 & $\begin{array}{c}1952,1962,1972 \\
1982,1992,2002 \\
2012\end{array}$ \\
\hline $\begin{array}{c}\text { Argonne } \\
\text { EF }\end{array}$ & STS17 & $\begin{array}{l}\text { Selection system to } \\
17 \mathrm{~m}^{2} \mathrm{ha}^{-1} \text { residual } \\
\text { basal area, with a } 61 \\
\mathrm{~cm} \text { limiting } \\
\text { diameter and a } q- \\
\text { value of } 1.3 .\end{array}$ & 3 & 0.6 & $\begin{array}{c}1952,1962,1972 \\
1982,1992,2002 \\
2012\end{array}$ \\
\hline $\begin{array}{c}\text { Argonne } \\
\text { EF }\end{array}$ & STS14 & $\begin{array}{l}\text { Selection system to } \\
14 \mathrm{~m}^{2} \mathrm{ha}^{-1} \text { residual } \\
\text { basal area, with a } 61 \\
\mathrm{~cm} \text { limiting } \\
\text { diameter and a } q- \\
\text { value of } 1.3 \text {. }\end{array}$ & 3 & 0.6 & $\begin{array}{c}1952,1962,1972, \\
1982,1992,2002, \\
2012\end{array}$ \\
\hline $\begin{array}{l}\text { Argonne } \\
\text { EF }\end{array}$ & crop tree & $\begin{array}{l}25-50 \text { selected trees } \\
\text { were released to } \\
\text { grow by thinning } \\
\text { the crown to a } \\
\text { residual basal area } \\
\text { of } 14 \mathrm{~m}^{2} \mathrm{ha}^{-1} \text { in } \\
1952,17.5 \mathrm{~m}^{2} \mathrm{ha}^{-1} \\
\text { in } 1972,17 \mathrm{~m}^{2} \mathrm{ha}^{-1} \\
\text { in } 1982,19 \mathrm{~m}^{2} \mathrm{ha}^{-1} \\
\text { in } 2002, \text { and } 21 \\
\mathrm{~m}^{2} \mathrm{ha}^{-1} \text { in } 2012, \text { with } \\
\mathrm{small} \text { trees left near } \\
\text { the crop tree as } \\
\text { trainers }\end{array}$ & 3 & 0.6 & $\begin{array}{c}1952,1972,1982 \\
2002,2012\end{array}$ \\
\hline $\begin{array}{c}\text { Argonne } \\
\text { EF }\end{array}$ & control & $\begin{array}{l}\text { Reserve area not } \\
\text { harvested over } \\
\text { period of study. }\end{array}$ & 3 & 0.6 & N/A \\
\hline
\end{tabular}

